Elena R. Menshikova

Candidate of Cultural Research, expert

New Institute for Cultural Research (Moscow),

e-mail: elen_menshikova@mail.ru

Moscow, Russia

OCRID 0000-0002-5738-0732

\title{
THE DOUBLE AXE OF MYTH (DIPHTHONG OF SONG) :THE FORGOTTEN FLUTE OF GREEK EPIGRAM / JUSTIFICATION OF VILENESS, OR TOTAL TRANSFORMATION «ACCORDING TO FAHRENHEIT» (CYNIC PARADOX)
}

\section{THE FORGOTTEN FLUTE OF GREEK EPIGRAM (PART I)}

Summary: While philosophers and poets quickly see their present, their "perception", left to contemporaries and descendants, slowly and not immediately begins to be perceived, and until they begin to "unpack" and it will be perceived (and probably not in the way the author expected), and when begin to hear in the voice of Cassandra who speaks again, it will be years, if not centuries, - and therefore it is important to understand that philosophers and poets always quickly see their present, in the hope of understanding the past, without which it is simply impossible to awaken either one's own Consciousness or a society that is always in hibernation, which, barely waking up, grasp at the flail, and the future does not bother them at all, because it exists only in the imagination, and which escapes as one approaches it. ${ }^{1}$ But many people are inclined to relate the "insight" to the future as a "process of an imaginary perspective", and only on the basis that it would be easier to relate its "allegory", that slipped like a fantastic drop, to anything, but not to the time in which it was conceived, it was written and realized as a literary work. It's like an invisible Creator from the noosphere spreads Perception and Allegory in different angles of the ring, so that the first will, like, put on

1. Perhaps this is a metaphorical resolution of Zeno's aporia about Achilles and the tortoise, but the best analogy is given by Russian Bylins - an image-allegory of Mikula Selyaninovich, who could out run the hero Svyatogor - for time cannot be caught up only when it stops itself. We have witnessed such a stop - how many Svyatogor revealed the "freezing of time" in world self-isolation? Maybe had come to an end reduced? weight, and the second will work on its technique, so that swing as a "resonant introduction" would occur as late as possible, but would be clear and accurate, and all-embracing, carrying such a powerful sound wave as the silkworms, mincing along the Great Wall of China, turned into the mulberry butterfly as fast as «insight could pierce», as quickly as someone else's perception arouses your "intuition" in you, which was dozing and delaying the exit, forcing you to search for new words, metaphors and expressions, sorting out overflowing wardrobe, and not finding «clothes» of the necessary palette. And since the process of «comprehending with an elusive allegory» is included in the act of goodwill of one's own Consciousness, then one beautiful or gloomy morning it will surprise itself, that is, it will open its eyes and "will be on shore in mail a-gleaming bright", being a consequence of the paradox of the mind, which we call the singularity of Consciousness that splashes in the temporal-spatial continuum of the culture that surrounds us and forms us. But we are talking with the «time» in which we live and while we live - there will be no other possibility. And so our "dialogues with time" turn out to be "elusive perception" for posterity. And the Greek epigram, peering by the dragonfly facets, throws to you just such an "elusive perception", the author of which, by inventing this very pop-eyed metaphor, prompting the Image of the Concept, forced people reading rhythmic lines to give a start by mind - and gain or remember moral principles, filling with sane sense or fun paradox that are positive, its existence, suddenly beaming with awareness, build- 


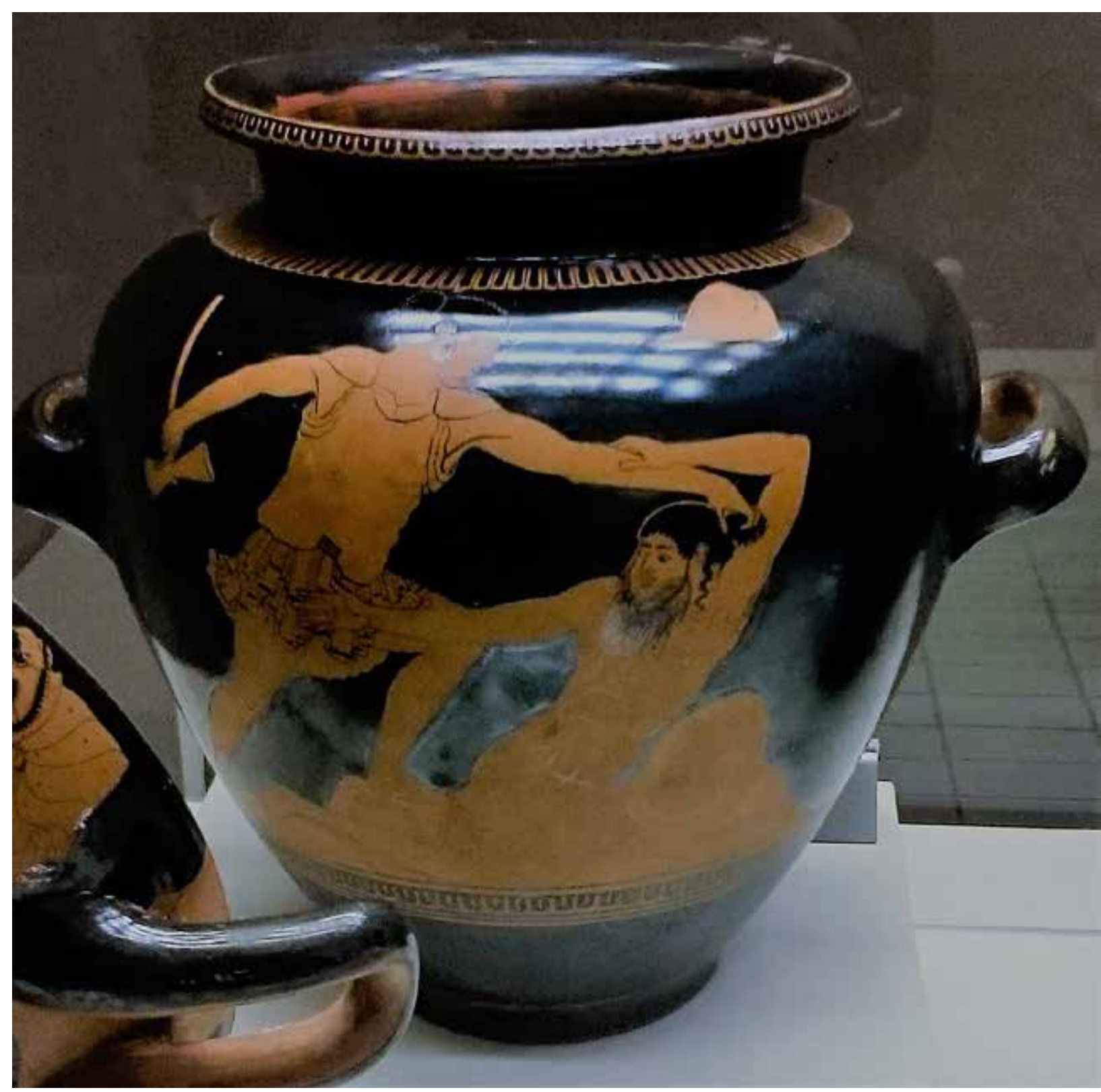

British Museum (Author's photo).

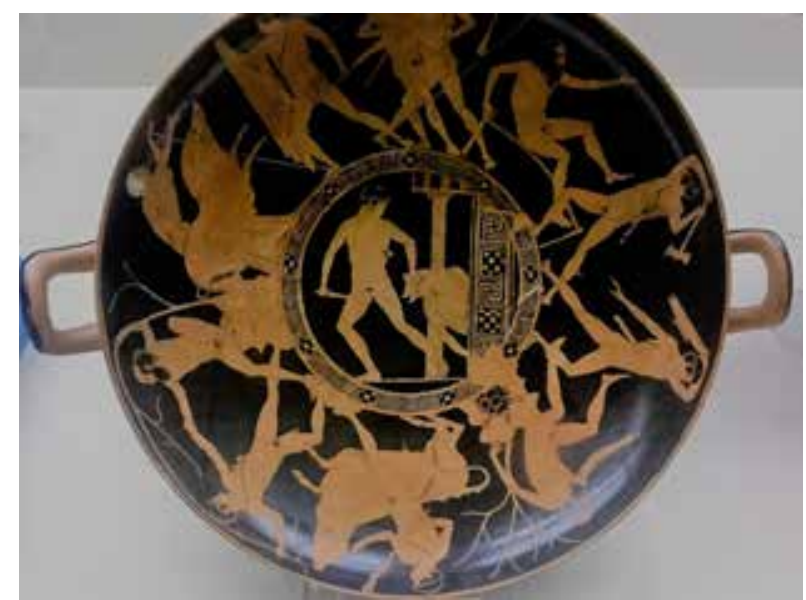

British Museum (Author's photo).

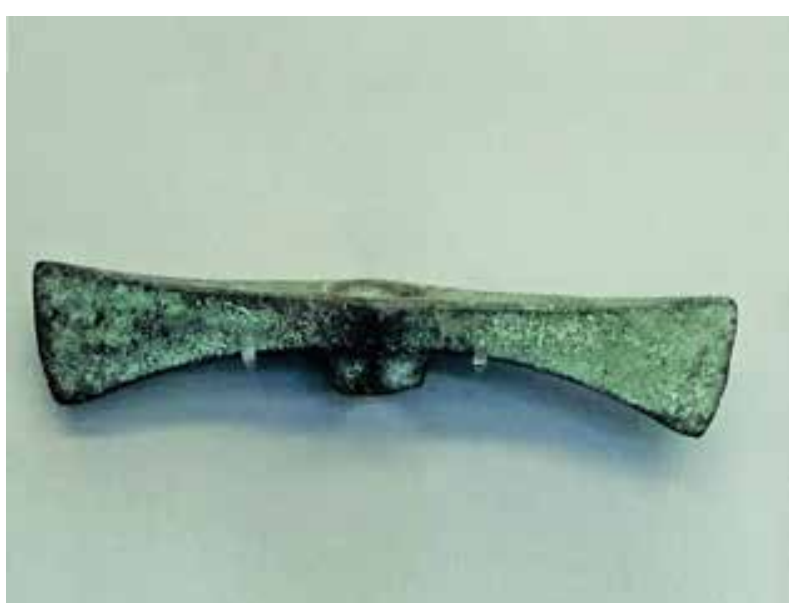

Double axe-head. Late Bronze Age, about 1100-900 BC. From Sardinia

The double ax, a hand-to-hand combat weapon, the most widespread weapon of the Mediterranean in the 2nd and 1st millennia $B C$, had undeniable advantages, allowing those who chose the pirate path to maintain mobility and determination: a genuine bronze ax (in the center of the first exposition) and an image on a red-figure vase, exhibits are kept in the British Museum (photo by the author). 
ing itself a crib of perceptions for all occasions from the contradictions revealed by the verse. The Greek epigram could act therapeutically, like the wise Asclepius, if her allegory was caught.

A thought like a lotus is always in the potential of revelation, always in the addition of itself from the petals of light - transparent blue-wings, which are not visible and not shining without a shadow and therefore, every thought is twofold, carrying its own "shadow" in the pocket of representation, as a non-contradictory contrast. The lotus acquires the power of magic only on the dark smooth surface of the pond or on its emerald sepal, which is opaque with dark umber, and $v \mu \beta \rho \alpha$ from Greek is a «shadow», which always has half-tones, but as the dusk of night is identified with «mysterious» and «secret», which always correlates with thinking - the mental perception of the visible and the sensed, for the ability to "see", and at night we precisely "see" - we not only feel with the pupils of the eyes, but we turn them inside ourselves, that is, we begin to think inside ourselves: visual impressions turning into linguistic constructions, because we think through words, translating the «visible» by the tropical path - a string of tropes - into the structure of the language, transforming the think-representation into the predicate of Idea - a verbal image. Polysemy (multivalue), without depriving a swift amble of speech, and with it clarity and melodiousness (a property of a native speaker of a certain linguistic tradition) of presentation - that jet stream of meanings which opens the door for the genius of insight, dooms you to wander in the darkness of your own consciousness until you are stocked up on a basket of acorns (words) - own language of expression, which will make it possible to plunge into the ocean of understanding with a wave of manta (giant oceanic manta ray), so that you can easily and simply, planting metaphors, see how seeds of perception are swiftly germinated and how semantic oakery is already pleasing with the magnanimity of its power. A metaphor helps you to think, and when we learn to think metaphorically, we more easily catch meanings - catching by cilia, luring like parus by grain of imaginative wafers - seating these tits as varicoloured blanket on our window, which, opening the world to you, always lets Something in with the Light.

The dual unity of ideas of the ancient Greeks accustoms them not only to unstable systems: revolu-
Key words: metaphor, Greek epigram, «elusive allegory», perception, Consciousness, Image of Concept, eidos, Image of Representation.

tions, polis organization, laughter, but also creates a precedent in culture - a dual model of art. The principle of "grotesques": to move from one body (hypostasis) to another - rests on three pillars of the ancient Greeks» conflicting thinking. This is their Proteus, in which the Stoics saw an allegory of matter that was formed and shaped by the very goddess of forms - Idothea. Such allegorical thinking could be formed only by Myth and thanks to Myth - this cradle of a person»s political reflection ${ }^{1}$, and only having received Proteus as confidant, a sea deity subordinate to Poseidon, who had the ability to take on any guise, predicting the future, and who was a symbol of plurality and diversity, and his daughter Idothea. ${ }^{2}$ It was she who prompted Menelaus the ways of returning to his homeland: to grab the sleeping Proteus and not let go of whatever form he takes until he is in his present form as an "elder" and gives advice on returning to Sparta, and reveals the fate of the heroes of the Trojan battle , - that is, she proposed a "form" of fulfillment of desire: materializing with a word, she helped to fulfill what was predicted and conceived, and thereby structured matter (including thoughts that are material «contrary to»), formalizing literally: directing and organizing. The werewolf of the sea deity was taken as the norm, while «irrevocability», which signified the law of predestination, initial prescription, the Greek of the classical era sought not only to avoid, but to ridicule. Idothea as a product of «matter» structures consciousness, formatting thinking literally: by vocabulary of language, syntax - an organized movement of words, and metaphor, helping to think, because we think in words. We note that

1. Details about the term "political reflection" in my articles "Myth as a natural exchange" and "The natural landscape of philosophy" [7, 9]; its essence briefly: it is a person's thinking that thinks of himself, rejecting the previous one as false or incomplete, like a snake shedding his skin, and thereby advancing to the length of his own body - and this is "first step" from which the political freedom of man begins. It will provide him with institutionalization, having formed a political (civilian) strategy and lifestyle. Russian philosopher A. Piatigorsky called "political reflection»" "thinking aimed at the political philosophy of the state".

2. The image of Proteus in the literature is used to indicate super excellence in something, or has an allegorical aspect in describing the quality of something or someone ("And his syllable is compliant and flexible, / Living Proteus, he took all the changes." Vyazemsky P. A. About Pushkin) [36, P. 125] 
such a double star Proteus-Idothea, merged into a dance, always seeks out forms of expression, and especially thoughts, and will always melt with the remorse of sunset, beckoning with the perfection of beauty and harmony, like a pink lotus - giving birth to the image of the sun, the Meaning that like an anemone will gravitate towards slipping, however, it will turn out to be the forever elusive Galatea, which is conjured or is cursing on the run, losing the perfection of forms, lines and petals of the mind. Thus, the situation with thinking (read, Consciousness) remains in the Saturnian embrace of Proteus, whose morphology is unsteady, but ringed by the fluidity of constant transformations and representations.

Olga Freidenberg ${ }^{1}$ claimed that "ancient literature is still in its infancy" and that it would be an absolute mistake to consider it "as something readymade in its form, as matter of course, long known" [39, P. 229]. As "a philosopher who does not recognize himself in this capacity" (N. Braginskaya) [38, P. 750], Freidenberg gave world science deep descriptions of consciousness, acting in a Proteus way and resorting to Idothea's mastery: allegorically, pushing opposing meanings within the boundaries of one word, culturologically conceptualizing the literature of the ancient world, and considering that "matter is through spiritual, and spirit expressed in matter" [38, P. 750], she saw in it perhaps the dancing pair of Proteus-Idothea ${ }^{2}$ - that ever-changing matter, always spinning and taking shape. In our opinion, such a description of thinking (worldview) that hit the reader with a stream of factual material from her book should be called a "second birth", because it was given through culture, which Freidenberg saw as "a part of nature and the universe" [38, P. 750] presenting and proposing a completely regenerative principle of «vision», practically a natural philosophical, that embraced the philosophy of classical Ancient Greece, letting in the worldviews of other cultures, but also because this principle of "explanation", being a philosophical interpretation, analyzed works of art that were already a «reflected perception» of being-in-the-world, the person

1. Freidenberg Olga Mikhailovna (1890-1955) - an outstanding Soviet philologist and thinker.

2. According to one version of the myth, Idothea - the Proteus's wife.

3. That's right: ancient thought began to return to Europe like the second birth from the "eastern captivity", thanks to the discovery of Gutenberg - through translations from Greek in Latin and typography, that is, "mass", for the end of the $15^{\text {th }}$ century, by replicating the works of ancient Greek philosophers, rhetoricians, geographers, historians, writers and poets. in it, and cosmos by the power of imagination and the thoughts of others and many, were already a «refraction» in art - the Image of representation.

\section{GREAT SCATTERING OF LAUGHTERSOPHY}

In Greece, philosophy was generalizing, but it also found a corner in elegant literature - in the Greek epigram, traces of which have survived from the $7^{\text {th }}$ century $B C$, where you can find soldered into speech imprints of the "satirical". In Rome, satire became an effective generalization, but Rome, and this is already the $1^{\text {st }}$ century $B C$, inheriting Greece and taking its culture and art together with space and population into its imperial borders, found itself in the framework of the critical self-awareness that Greek philosophical schools (opened at different points in the metropolis) bequeathed, enriching it with wide illustrative material in the spirit of Goya's grotesques - not yet born, and poetic satire. "Mockery" as a "kind of generalizing thinking" of the ancient Greek (that collective "Greek" as a representative of Greek civilization) after three thousand years we can catch in miraculously preserved artifacts scattered in the island museums of modern Greece - in ceramic sculpture (miniature) of a grotesque image (Samos, Rhodes), grotesque vase paintings (almost everywhere), wall paintings (Akrotiri's frescoes), and especially in the Greek epigram. The modern meaning of the word "epigram" somewhat does not coincide with its original denotation, which literally meant "inscription", being actually an inscription on tombstones (epitaphs) or on statues, tripods and other objects donated to a deity (initiation), and that were are short and written in poetic form, mainly with a hexameter. ${ }^{4}$ Here is an example of one of the oldest:

"A lot of crows on a cliff feed on fig tree fruits; Kind Pacifila is glad to receive all guests» $[2$, P. 5].

This is the epigram of Archilochus, who lived in the $7^{\text {th }}$ century BC, written on the death of hetaira Pacifila. He was revered on a par with Homer, considered to be the "father of satire and iamb", one of the founders of Greek versification (which does not work without generalizations (!) and is impossible), the inventor of "archilochic verses", in the shortness of which the wisdom of understanding was reflected, which are revealed an extant sample of the first

4. See: Greek epigrams (VII century BC - IX century AD). Translation, article and notes by L. V. Blumenau. - Moscow-Leningrad ACADEMIA, 1935. - p. 316. P. XV. 
satire epigram to descendants, like a whisper of a dragonfly gives a perception of human existence, which was not clearly "bad" or "good". Hetaira as «a fig tree» ${ }^{1}$, which quenches and feeds by the kindness of nature (and at the same time takes money for services) of anyone who was nearby as a lone raven or crow, and she is extremely lonely: alone on a cliff - and everyone can see its curvature and broken branches but her friendliness, bestowing "benefit" on others, serves her both as a mockery and comprehension - her modus vivendi (hetaira - the status of "socially reduced responsibility") will always be ambivalent, with a double bottom, and served in satirical coverage. And here Laughter "works" on a metaphor - through the allegory that turns "exaggeration" into the Image of Generosity, that it has learned to take advantage of the "benefit" (directed good) that it does to others. Archilochus, as Proteus of the satirical iamb, whispered the dithyramb by a couplet of transparent wings about the leprosy (like «prank») of the world - prostitution, which was and remains leprosy on the body of society, oppressing the vicious circle of irresponsibility. And here we oppose Olga Mikhailovna which did not see satire in Greece (see above), but it was, and was revered as a fig tree, or hetaira, for it shone sparkling in the most prominent and significant places of society - the mark of the monument/sanctuary, throwing spear of Meaning, that is, it was spread as a "generalizing thinking", intended for many as a collective statement about a particular that carries or has generalizing features. And so the epigram by Anacreon: "Timocritus was courageous, buried under this slab. Apparently, Ares spares the faint-hearted, not brave» [2, P. 10] - as the "epitaph to the warriors" conveys not only the skepticism of the former warrior, but also his sarcasm: only a coward will survive in the war, and who shares his understanding of the injustice of the world - do not wait for mercy from laughing Moirai that they don st take revenge, but mark, giving reader its comprehension of those incidents of life»s vicissitudes that contrary to the observance of moral rules and manifested valor, turn out to be usual in their regularity of defeat, that they take the life of the righteous man - giving a scoundrel, and this

1. A subtropical tree, strongly curved with a spreading crown and dense foliage, giving a lot of shade, with an abundance of sweet and nutritious fruits, saturated with useful trace elements, with porous wood replacing fuel, which was revered by the ancients along with olive, being considered "paradisiacal", symbolizing God's blessing (Bible), health (Koran), personified peace and prosperity. bitter smile, which, using the reverse order of words, creates the "denial" in which the cherished needle is left - a mental generalization. And as a Koschei's inheritance, it was left by the one who were at the epicenter of the political events of the century, like a strategist bitten by poison, who comprehended the treachery of the world, who spent their young years at the court of the tyrant Polycrates of Samos ${ }^{2}$, who created a gigantic (for that time) navy, built the first underground aqueduct ${ }^{3}$, who "ravaged the lands of friends and enemies indiscriminately" (Her., III, 39), who turned Samos into the largest maritime and commercial power of the middle of the VI century $\mathrm{BC}$ in the simplest and easiest way - «style» of piracy $^{4}$, and who gained fame as a brave builder (his aqueduct was built before Euclid and its geometry, but by all the rules: its Gothic arches did not collapse, water continues to flow, functioning as a kilometer tunnel at an eight-meter depth to this day). With such a gentleman, it»s difficult to remain in the hypostasis of a "lyric poet" - it is precisely the epigrams that betray Anacreon as the acrimonious cynic wise due to the vicissitudes of life - the iambic Thersites, who, passing half his life, suddenly found himself in a gloomy forest (I believe that the time of writing coincided with the death of Polycrates or with period "after"), managed to navigate the terrain and ... change patron - to Hipparchus, having moved to Athens. Life itself, full of military battles, deceits and dirty tricks, served as a justification for his mode of existence - Aesop's cricket at the court

2. Anacreon (middle of the VI century BC, Teos (Ionia) - lived about 85 years, Abdera (an ionic colony on the Thracian coast)) - Ionian lyricist who spent his best years at the court of Polycrates (574-522 BC) is a successful pirate who inherited power from his pirate father (that is, who seized the island), who created a flotilla of many-oared ships that guarded the Aegean Sea with adjacent sea routes and fishing season, but even more replenished the tyrant's treasury due to raids and robbery, about whom not only Herodotus begins its narrative, but also Thucydides, who also cares about the region's economy (wool manufactories opening on the background of livestock development), trade expansion (own minted coins) and infrastructure (underground aqueduct, bridge, roads and temples, urban architecture and etc.); and after Polycrates's death he moved to Athens to Hipparchus (d. in 514 BC) - a tyrant from $527 \mathrm{BC}$.

3. The underground aqueduct, which was built for nearly twenty years, also served as the "bomb shelter" of the ancients, being a kind of the first line of the "Samos metro" - a double tunnel: for water (lower flow) and for people (upper road where a person can go without bending).

4. The most common weapon in the Mediterranean is the double ax (a small hatchet with a bronze tip from a double-sided backsword) - a melee weapon whose rare specimens dating from the $11^{\text {th }}$ or $9^{\text {th }}$ centuries $B C$, can be found in the British Museum, and even in the museums of Samos. 
of the king, who was not brave like Arthur, but masterfully possessed a caustic mockery.

"Next, graze its flock, shepherd, so that Myron»s heifer, As a living, you can»t steal with other cattle» (On the bronze heifer by Myron) [2, P. 11] - this is an epitaph to the bones of a stolen cow (apparently a sham, because it was stolen), which is interspersed with a mockery of a careless owner who, knowing about the pirates, does not worry about the safety of his flock, but erects a bronze statue on it (which is not reasonable and not practical) - and in this case, the Anacreon's epigram, echoing the Hesiod's "teachings» in "Works and Days," which introduced the laying of the rules of everyday life by philosophical generalization, instructing to be a assiduous host and active person, it suddenly flew by a two-winged fidget (couplet) - tuning to the critical way by a malicious smile about the imperfection of human nature, ridiculing the vanity of the rich man and his "crocodile tears." So «a bronze cow», growing into a gravestone, turns out to be «a symbol of hypocrisy and stupidity», revealing the Image of a concept. On the example of Anacreon, it is noticeable that the lifestyle and patrons greatly influenced the creative muse of this poet, who had a penchant for fables, was able to distinguish wheat from the chaff, but who has gone down in history as the author of erotic lyrics, which will change his lifestyle to "hedonism" and contrary to the popular credo of "piracy," which has been cultivated century after century, and "violence" that has come into fashion, and that it will boldly declare:

"My dear to me is not the one who, feasting over a full bowl, speech Only about litigation, but about an unfortunate war; My dear to me is the one who, combining muses and Cypris's good gifts, Makes the rule - to be more fun at the feast» [2, P. 11].

Here anaphoric denial introduces with irony, and, bitterly, that «mental generalization» about the real being-in-the-world for the poet Anacreon, which is filled with vanity and pretense, and only by the power of the mind and the desire for harmony (which is possible only through art) it is possible to get out of false ideas about the world and the cosmos, from the captivity of vicious illusions and delusions, finding Meaning in the service of the muses. The Athenian tyrant turned out to be the exact opposite of the tyrant of Samos - preferring muses to violence, replacing the blade with art, turning their lives into love affairs, but having lost the respect of citizens and the throne for their peacefulness, that is, be- ing a pacifist, for non-conflict and non-acquisitiveness. However, such an "understanding" is available only to those who, without changing the status of the court poet - the squire of rhymes, and part-time jester, will comprehend the ambivalence of life itself - in battle and at a feast, taking both positions as two sides of the same medal, having experienced two «routines» of articulation, and consolidating the true by laconic praises that was in wine, considering the war as culprit of all troubles. Therefore, the poet, who composed epigrams and counted the rhythms of his own heart, and saw the arrhythmia of the era with the naked eye, was a philosopher who spoke with this era by the language of the satirical dithyramb (more precisely, its sprouted grain).

\section{DACTYLIC AFFIRMATION OF MEANING}

Note that we interpret the Greek epigram not of the heyday of Roman satire (I century BC - I century $A D)$, but the times when Rome was not only an «empire», but only began its modulations to capture foreign territories playing the adaptation of «Sacred Rome`s Terra». Elegiac couplet in which the hexameter (six metric feet) of the first verse is replaced by a pentameter (five metric feet) by truncating the third and sixth metric feet - the so-called dactylic iamb, giving the poem a certain completeness that did not require "continuation", like a hexameter, but prosodically balancing long and short syllables in verse, breaking into two equal (2.5 dactylic feet) parts by caesura, - a brief judgment, or a verbal formula, that reinforce the Image of representation raised about the subject, to which the epigram was dedicated, in multiple replicating (and epigrams were read more than once and recited wherever possible, transmitting and transferring the «content» from the place of writing (sanctuary, grave) through cities and villages on the speaker»s verbal boat). Working to strengthen and reinforce this representation in the consciousness (one's own - for the speaker, and another's - for the perceiving phonetically), this contributed to the emergence (or the addition of mental and visual representations from "pictures") of that Image of the concept of an object or phenomenon, which turned out to be "mental generalization" an aggregate representation of "understanding», which was accepted by many for objective reasons: the coincidence of sensations, perceptions. So the thought is organized rhythmically so that the rhyme takes on the character of a philosophical aphorism, 
which would be remembered by itself due to the musical rhythm of pitch stresses $(\pi \rho 0 \sigma o \delta o \sigma)^{1}$, turning the meaning in the licorice wrap of a laconic phrase, becoming a kind of affirmation ${ }^{2}$ of comprehension. And since every epigram had its own author, being a «subjective affirmation», it turned into a satirical generalization by mental images (sometimes sarcastic, sometimes skeptical), that the Consciousness discerning distance, or Providence - that Idothea paired with Proteus - framed «understanding" with an ironic allegory - a metaphorical paraphrase, in which the polysemy of the word had the primary meaning as the ability and tendency not only to neologism, semantic polyphony, but also as the possibility of "reality of maieutics (Socratic method)" - reproduction of thought, creating a precedent for the birth of "Image of the concept" through overtones of Laughter, which became a worldview and a frame of reference once and for all. Polysemy (the predisposition of the word to ambiguity) is a sure chance to "conceive": to become pregnant metaphorically - the ability to be filled with metaphors, or various reflections and gleams of the Sense, and in adjacent projections and with other filters. And this is not so much a passive pledge, but a guarantee of longevity of the image of the concept that is born from a metaphor and by a metaphor - a transition: from metric foot to metric foot ${ }^{3}$ - by a metonymical collection of values.

The laughter of the Greek epigram is the winter Solstice: in it the severe cold fought with light, the grief found a reasonable explanation of what hap-

1. The prosody (from the Greek $\pi \rho 0 \sigma o \delta 1 \alpha$ - literally "chorus", "stress") is the historical section of the ancient grammar devoted to stress (originally musical), as well as the longitude and shortness of syllables. In the 18-19 centuries, prosody was called the totality of the rules of versification [36, P. 298]. In the modern sense, the term is identified with the concept of "rhythm", and is used to denote the elements of the language on which this or that versification system is built, that is, it is used as a «structural generalization».

2. Affirmatio, onis - "affirmation», "assurance» that supports something (e.g. hope, faith), reinforcing and attaching perception $[4$, P. 24].

3. The metric foot (from the Greek tropor - "phrase") is the use of a word in a figurative (not direct) meaning with the help of secondary semantic nuances and not directly related to its main meaning. The correlation of the meanings of the word (direct and figurative) is based on the similarity of the comparative phenomena, or on the contrast, or on their contiguity. The main types of metric foot: metaphor (similarity and contrast), metonymy (contiguity), synecdoche (ratio of part to whole), epithet, comparison, litotes, hyperbole, irony [36, P. 427]. A metric foot is a general phenomenon of language, which extends its capability of understanding, moves apart the boundaries of usage - the actual speech landscape, deepening the representation and perception of phenomena or objects. pened - through the turn-swirl, the meaning was realized by the turn of Laughter: it's similar to the passage of the way through the allegory - that artistic path of «foot», which is released by the thought that was doomed to life (as the inevitable arrival of spring after winter), to light - that's why these early laughable forms are called lustration ${ }^{4}$ - light, freeing from despondency, fear, grief, painful thoughts and doubts. And these are all the mental operations on which the ancient thought was oriented (as a product of the mind indistinguishable from the modern one, we note), and which were operated by natural philosophy, whose gamma rays are dissolved in Myth, and like divergent ripples on a pond, they are present in it by images of representations endowing with understanding about the structure of the world, knowledge of interdependence - the set of keys of determinants ${ }^{5}$ sooner or later appears on everyone's belt, and then the forces of nature $(\phi \cup \sigma i \sigma)$, becoming closer as anthropomorphic gods, become clearer through this metonymical keyhole, in which they accustom to look from childhood, revealing the logic of the "act" (or manifestation) of that action or phenomenon that gravitating to abstraction, will turn into a Concept, since our anthropological Siamese (psychological and physical instability), causing mockery during the untwisting (storytelling) of the plot thread of one or another Myth, presenting in an unseemly (from the point of view of Agon and ethos) situation, handed the cipher to the determinant: the boundaries of the permissible and unacceptable, helping solve the most difficult tasks of self-preservation and life support. Our whole life consists of solving such equations - a system of picaresque moves (combinations) along a lined coordinate grid, Life is materialized in a mixture of linear and nonlinear tasks (by the example of the life vicissitudes of Heracles or Hermes, we can track how one preferred linearity, suffering for his honor and honesty and the other resorted to non-standard solutions - and won, but by deceit, becoming the patron of thieves (rogues), the creator of the lyre, announced by the messenger of half-tones, - the sons of God, Zeus's seed, but of different attitudes). Through Laughter (rid-

4. Lustro, avi, atum, are - I) to illuminate, 1) direct: about the sun; 2) figurative: a) to examine, to inspect, and to inspect by $\operatorname{mind}=$ to perpend, to ponder; b) to pass, to bypass, go around, undergo; II) 1) to make light, 2) to purify by offering a purifying sacrifice, to sanctify [4, P. 372].

5. The determinant (from the Latin determino, determatum "to limit», "to define») - math. determinant, expression composed of matrix elements; solutions of systems of linear equations are found by dint of the determinant [3, P. 157]. 
iculing the sacred), a person returned to the light - to the gleam of comprehension, freeing himself from the fetters of delusions (mental straying), and from censure (dogmatic fears), passing the Solstice of Laughter - the gates of cooling and enlightenment, while leading all of humanity. Lustration (purification) as a ritual of sacrifice is associated with the funeral feast, funeral repast, sacrifice, which is already paid by burying, comprehending the living existence of the deceased (modus vivendi), at the same time mourn the buried, but remember only the positive. It is the same in the Greek epigram, which at first was intended for lustration of an subject/object covered by a gravestone, when the rite of "purification" occurred by the recitation of the verse-epitaph inscribed on the same stone - the sacrifice was sanctified by illumination (a stream of mental images) and thereby it was cleansed of grief and shame, by revising delusions and blunders, freed from past fears and doubts, but with alien eyes, as if by "outside" interference. And if the Roman satire in literary science has long ago and thoroughly strengthened itself as the "lustration genre», then the Greek epigram can also be correlated with this genre only on the basis that the latter preceded the satire and was closer to philosophy, for it was and was built as «a thoughtful generalization», that, subjecting it to thoughtfulness, is weighed - by exclusion - looking at the comprehended object into the "gleam» of the mind, made a judgment, which freed us from delusions, granting insight as an «understanding» of the object/phenomenon: whether a person, war, or cosmos - it overshadowed (right above the tripod or grave) with aggregate and objective knowledge about the vicissitudes of fate, people's actions, unbalanced and spontaneous being, preparing to accept possible and probable circumstances (similar to what the "victim" experienced), comprehending, precisely passing alien`s Deception.

\section{JUSTIFICATION OF MEANNESS, OR THE TOTAL TRANSFORMATION "TO FAHRENHEIT" (CYNIC'S PARADOX)1}

Abstract. Myths are rewritten, ethos are corrected due to the socio-political instability of life, a person is reformatted from time to time, and the humanities continue to uphold sanitary standards and the inviolability of their fundamental boundaries. Discoveries in geology, biology, astrophysics, only the last fifty years, reveal, confirming Heraclitus's catch phrase about the unstable variability of the world, its inconstancy and fluidity, but philosophers have ceased to question the truths that have been established to the extent of stone idols from Easter Island. Refusing to a new look at the primary sources, scanning the meaning to a quantum - and not leafing through it like a gadget, hearing and listening to the sound of the paral-

"Newtons with quick mind" haven 't got the time to reach the heights of truths, because almost all of them are engaged in another department - ra-

1. A fragment of a book sent to print, but the title itself was coined at the end of January 2020 for the summer annual philosophical conference in Greece, and the contents of this short article are extended theses for a failed scientific expedition due to Covid'19, and is dated May 2020.

2. A metaphor that uses the allusion to Bradbury's metaphor "Fahrenheit 451", from his famous story, which literally means the ignition temperature of the paper, but has become a symbol of resistance. lels that arise, we include Fahrenheit $451^{2}$, which threatens the heat of the Arctic cold - not just oblivion of cultural memory, but the inability to understand the mistakes of its predecessors and the courage to correct them. Such an "absolute zero" can hardly testify to the flourishing of the culture of modern civilization, which was not comforted by philosophy, because the virus of self strongly supplants all doubts and reflections, being content with a short course of hastily compiled textbooks and clichés of abstract dotted lines.

Keywords: Consciousness, Image of concept, singularity, hidden metaphor, Meaning, violence, the cynic's paradox, continuum, dichotomy, hypocrisy, capture as a formality.

tionalization and modernization, engaged in the expansion and popularization of the matrix systems of postmodernism. Such a "technology" of mental activity, devoid of political strategy initially, depicts a non-commissioned officer's widow addicted to Saturday flogging rather than attacking the imperfections of the peripatetics world, since the young humanists are not embarrassed, as if nihilist-Bazarov's decapitated shadow is behind them, demonstrate their immaturity and unpreparedness for independent thinking, otherwise, to improve, 
but only to clone previously expressed. Let me ask how a lover of anxiety doubts: what is the criterion of "scientific" today? Is it really from the number of references to foreign works (analog, but far from identical in meaning and essence)? (an you really convince yourself of your thoughts (and yours?) with the number of other people's quotes? How to recognize / see it in the midst of other utterances uttering as snakes, by the diligence of a schoolboy who is copied by cursive? As if they seek to patch holes on their scientific mantle with quotes. Perhaps the troubles in society are because the philosophers are obedient to Calderon's harp, and have not been ashamed of their "gap" for a long time, as if they are all Diogenes, painfully crowding in the shell of their ego. At the same time, while advocating for changes in society, thinkers are not ready to revise universals and concepts, apparently afraid to recognize the fatal constant of the person himself, which for four millennia remains stubbornly stable in its manifestations of immaturity and self. And in essence: simplified by idleness and universal education - the person of «the consumer society» is closer to the Cro-Magnon Man than to homo sapiens. Note, explicit statements about scientific knowledge, about scientific concepts and theories, appealing with constant (once and forever accepted) terms, which speaks of the dogmatism of recognized "truth" once and for all, least of all contributes to revolutionary breakthroughs in the scientific field, but provokes stagnation from progressive sclerosis of copying technology and methodology.

Ray Bradbury played the "transformation" that happened to his native society, his people by the title, and if Kafka had his own perception of the anthropological changes in society in the 1920 s presented quite naturalistically: by surrealistic assimilation into an insect, then Bradbury in the 50s invented an abstract metaphor - «Fahrenheit's fire». And if you stick to the figure that was put in the title, then it corresponds to Celsius 232 (the temperature scale that is familiar to Russian and European), and this is not only the temperature of "paper ignition", but also the self-ignition of crude oil (226-246) and peat (225) ${ }^{1}$. And if Bradbury meant the latter? Peatlands burn for a long time, hidden, deep and extinguishing them is not that it is useless, but painfully difficult, and then 451 is not "burning", but smoldering, and in this case, it turned out to be extremely ac-

1. According to the school table, the burning temperature of a match or flame is $700-800$ degrees. curate and expressive - he depicted the smoldering of the human breed - not death, but "stinking", for, we repeat, the main meaning of the novel is a transformation of meanings, not a literal burning of books, and the cool of dehumanization will kill humanity. We believe that the writer was primarily concerned about the vicious life-style of the growing city, spreading of the smell of burning, the disadvantage of Consciousness in it, that deprived of originality and independence, forcing to games with conscience, honor and mind, mankurtizing and thereby likening, leaving out the law - the Spirit of the ancestors, which must be inside each a priori.

At the same time, I note that the idea of "globalism" that emerged during the time of Alexander the Great, rethought in the color revolutions of the $20^{\text {th }}$ century, sprinkled with hippie ${ }^{2}$ juice, inherently carried the spirit of socialism, and therefore Europe and the USA are now saturated with the communist ideas of anarchist rebellion this can be considered as a result of long containment and desolation: McCarthyism vulgarized a person, restricting it to control and prohibitions, by circular hypocrisy, the hypocrisy of Capital - and now Eidos needs a birthplace, again, this is the law of conservation of energy, or the law of life according to Heraclitus: from the struggle of opposites, the new is created as the Demon of contradiction, true or not, it is not yet clear, the main thing is "new", however, it seems that the "new" turns out to be the forgotten "old", patched and turned historical rags. ${ }^{3}$

2. The youth movement, which originated in a foreign musical rock environment as a result of the spread of ideas of American existentialism in the late 60 s of the last century as a protest against the color revolutions and local wars conducted by the US army and its allies in the bloc. Not to be confused with modern hipsters.

3. A remark that arose unexpectedly: like "after" the already introduced additions, whose the real suddenly gifted a surprise: arguments of undeniable evidence - a truly planetary protest movement began since the end of May 2020, replacing the planetary civilian self-isolation of countries caused by the coronavirus pandemic, and which can be likened to medieval peasant uprisings, and the essence of which has yet to be comprehended. And while a footnote to "Fahrenheit 451" was being created (on the recommendation of the editor), international media reported that in the USA, against the background of mass protests and pogroms, they had introduced racial censorship, and began with the textbook film "Gone with the Wind" (1939) - having removed from digital carriers of the movie, and the novel "To Kill a Mockingbird" by Harper Lee (Pulitzer Prize 1961), which brought up generations (and not only in America) that have become classic of «world art» - and this populist gesture is akin to marauding, and only testifies that McCarthyism's spirit has taken root in the lymph of the whole American society, which is based on the Protestant Inquisition, the struggle for exclusivity and «persecution of witches». 
After all, "Fahrenheit 451 " is also a symbol of irreconcilable courage, and the transfer into a different temperature scale, that every non-American reader unconsciously makes in his head every time he sees the footnote "Fahrenheit», turns out to be a "call to return the transformed meanings", tacitly lost or scolded suddenly, erased and forgotten like that denotation of a "fireman" that from a "fire extinguisher" turned into a "arsonist". It's time to bring back the meaning of the word "extinguish"! It is impossible to get away from the transformation of meanings that has occurred or is happening (to the exact opposite) at once and instantly, escaping in one fell swoop, how it's difficult to dodge a snowball or a lump of dirt flying at you, but when your consciousness is stoned and a fatal outcome is almost a foregone conclusion, then it is possible to avoid, if you abide by the rules of hygiene, for Consciousness first of all.

"Fahrenheit 451" is also a parable about the upcoming expansion of an aggressive state, which will stretch as a smoldering swamp around the world, forcing the world itself to transform and meanings and value categories (good, evil, love, beauty, knowledge, etc.) by violence and deceit; those cultural meanings that turns out to be common for each nation, since it is fixed by tradition (literary, ethical, musical, folk, domestic), and thereby legitimizing depersonalization, as if pushing, awaken the worthlessness of the modern person who is forced to become a "renegade" - a person without historical roots, without a homeland, without the home of ancestors, mankurts of the primitive, immersed in surrogates of a consumer society, but all smoldering is replaced by a flame - protest flashes like fire, and sooner or later, but that's when it gets unbearable - put up with the cold of alienation.

The revolution is that state of society in which everything is allowed, and as a «state» it was introduced by cynics (hubris) who had nothing to lose, because they had nothing for their souls, but perplexity and ego, and the revolution, as a «state», appealed to civilization, which adapted it to the "fashion" and accustomed humanity to fight for the "right to own", while revolutionism became identified with the "struggle for freedom", and the latter, getting lost in broad daylight, not noticing the transformation, leads to the wall of the reservation of the totalitarian regime. How? - by ignorance, and unwillingness to know more than a circular. The state in which everything is allowed to a person is rather shapeless, and the society itself is amorphous and forgetful, and therefore it does not notice the "transformation" that is happening to it, since it is accustomed to stop History - cut its curls like dog tails, and therefore it easily kneels, because Consciousness has been on its knees for a long time, and until this kneeling rebellion peers into itself, at least through the mirror of metaphors, - the totalitarian and total will swaddle, directing a society that does not notice its transformation, as Gregor Samsa ${ }^{1}$ did not notice his "transformation", not accepting as its "reflection" an arthropod insect, it will be malleable to all manipulation and information, inclined to any affectation, it will tremble and be hysterical, and until it realizes the limits of its Consciousness (at the same time, each individually and each in its undivided aggregate - totius), that is, his ability to comprehend everything and all, then there will be no sensation of the «transformation» that happened to him, nor will there be an understanding of the "beauty of the world" as the totality of "harmonious" and "human". A premonition of a total transformation ${ }^{2}$ taking place in human society, which devastated itself, burning the meaning, as a premonition of a great misfortune: the disappearance of the prospect of existence (not the future - it's just a "temporary category"), as the insight of the existential failure into which the consumer society flew, sweeping away all foundations of the existence by fire of rational hypocrisy - it is precisely this "insight of time and space" that Bradbury expressed in his novel. And "total" in this combination means complete, comprehensive, like a wrapping, which Proteus demonstrated by undergoing a complete metamorphosis: from a fish to a wild boar. The firefighter, who considers "igniting fire" his direct professional duty, but not "putting out the fire", is proof of a "completed transformation", since the profession carrier has forgotten the meaning of the word, which defines his occupation, as well as the baker, "baking", would process the buns by a chemical solution, turning them into "poison" (analogies can be expanded), and maybe he would like to recall the etymology of words, but it's bad - dictionaries, as the "enemies of the people", were burned first. And herein, the real catastrophe of society - in the total loss of meanings, loss at the cost of not distor-

1. The character of the story by F. Kafka "The Metamorphosis" (1912).

2. From: "transformo, avi, atum, are «transfashion», «transform»; transformis - «changing», «changing its appearance» «changed», «transformed»"[4, P. 656]. 
tion, but complete replacement with the "other". The symbols of the transformation can be different: from the butterfly and Proteus to Saint- Exupéry`s hat-elephant, but their essence is unchanged: they carry the "text message" about the transformation that took place. "The Wild Swans" as a symbol of transformation through the elusive perception and identity of the resonant burst allowed my Consciousness to interpret the Bradbury's metaphor into a symbol of transformation, revealing the "appearances and passwords" of this perception of the struggle against dissent, which had been secreted since 1953, which so frightened the strong newsman Ray, and he managed to warn about the prolegomenon and flashes of the impending decline by "Fahrenheit fire", making it a symbol of total transformation. She's already coming. But as a "smoldering" it will be long.

The dual unity of ideas of the ancient Greeks accustoms them not only to unstable systems: revolutions, polis organization, laughter, but also creates a precedent in culture - a dual model of art. The principle of "grotesques": to move from one body (hypostasis) to another - rests on three pillars of the ancient Greeks' conflicting thinking - this is their Proteus, in which the Stoics saw an allegory of matter that was formed and shaped by the very goddess of forms Idothea. Such allegorical thinking could be formed only by Myth and thanks to Myth - this cradle of a person's political reflection, which, in essence, is a person's thinking that thinks of itself, rejecting the previous one, doubting it like a snake, throwing off the skin, and thereby: moving to length one's own body - it really paves itself - and with this "first step" begins the political freedom of a person, which will provide him with institutionalization, having formed a political strategy and lifestyle. Note the Russian philosopher A. Piatigorsky called political reflection thinking aimed at the political philosophy of the state.

It was Idothea who prompted Menelaus the ways of returning to his homeland: to grab the sleeping Proteus and not let go of whatever form he takes until he is in his present form as an "elder" and gives advice on returning to Sparta, and reveals the fate of the heroes of the Trojan battle, - that is, she proposed a "form" of fulfillment of desire: materializing with a word, she helped to fulfill what was predicted and conceived, and thereby structured matter (including thoughts that are material «contrary to»), formalizing literally: directing and organizing, and if literally: close to the source, it aroused the stra- tegic dexterity of the king, who found himself in a difficult situation and rushing to his homeland - to the state: to possess and rule. The werewolf of the sea deity (Proteus) was taken as the norm, while «irrevocability», which signified the law of predestination, initial prescription, the Greek of the classical era sought not only to avoid, but to ridicule. Idothea as a product of «matter» structures consciousness, formatting thinking literally: by vocabulary of language, syntax - an organized movement of words, and metaphor, helping to think, because we think in words.

Criticism of the latest misconceptions, exposing the formal approach of logical premises, indicates that humanity has made an evolutionary rebound of 2.5 thousand years, digesting the liar's paradox into the cynic's paradox: widely and freely using the binary code of hypocrisy, demonstrating its cunning, but alas, formal mind, accustomed to incline logic into a "formalism", which has lost the form of Sense. The Formality of Deception as a technique of «blooming hypocrisy», and as the trick of Consciousness, which is lost or got confused in a very simple matter, reduces life to a certain form that is not demanding of emotions, which suggests sincerity and trust, and formally accustoms to imitation and rituality - emasculation of an act, - and this is truly a rollback to archaic - treacherous and dark centuries, which, in fact, turns out to be the "software" of the thinking of modern human. The formal mind demonstrates its readiness to deceive and overreach itself, as in ancient times in a hunting battle, having a gadget in your pocket and a university behind your soul, that is, it perceives a priori a lie, worshiping violence and dreaming of power (including surrogates of these concepts) outside of a conflict situation, but provoking a conflict. Such a turn of our thoughts to our concept of "Trojan terrorism" is not just evidence that the author is influenced by his idea - on the contrary, it is an Idea, having acquired the Image of a concept: capture as a formality, owns society as a sovereign, establishing its Principle, demonstrating freedom wills and completely the Martian chronicles of existence, relying on the «multiple unity» of consciousness, which is structured from the outside by the formal method of Cubo-Futurism. The formality of prejudice, emasculating life as the life of others, removes all logic as "excessive formality", preparing the ground for a crazy life - embodying the insolent fellow's life as being an infant - continuous in its idle atti- 
tude, covering Consciousness itself with the patina of hypocritical lies. We are not born blind, but Consciousness - our vision - is a guide to the infinite and knowable, and therefore this article unwittingly demonstrates that the criticism of spotless mind is easily transformed into a criticism of the formal mind, unpretentiously exposing the morphology of author's consciousness, for which the concept of "Trojan terrorism" and the concept "swinging consciousness" forms the libertian tango, in the "nonfusion" of which the Image of the concept is born.

\section{REFERENCES}

1. Aristotelis fragmenta selecta, Recognovit W. D. Ross. Oxford, 1955, p. 183 (in Russian)

2. Greek epigrams (VII century BC - IX century AD), Translation, article and notes by L.V. Blumenau, Moscow-Leningrad, 1935 p.316 (in Russian)

3. Kupriyanova, V., Umnova, N. 1996. Concise Dictionary of Latin Words, Abbreviations and Expressions, p. 96, Moscow (in Russian)

4. Petruchenko, O.A. 2017. Latin-Russian dictionary, Moscow (in Russian)

5. Lurie, S.Ya. 1970. Demokrit. Teksty. Perevod. Issledovaniya [Democritus. Texts. Translation. Research], Leningrad, p. 664 (in Russian)

6. Menshikova, E.R. 2016. " Apologiya Smekha: singulyarnost» «grotesknogo soznaniya» v sisteme lokal'nykh voyn, ili umolchaniya Aristotelya kak "sryv potoka"" ["Apology for Laughter: the singularity of "grotesque consciousness" in the system of local wars, or Aristotle's silence as "disruption of the stream"], Materialy Vserossiyskogo nauchnogo seminara s mezhdunarodnym uchastiyem «Corpus Aristotelicum v XXI veke» [Materials of the All-Russian scientific seminar with international participation "Corpus Aristotelicum in the XXI century"], April, 14-15, Crimean Federal University. V. I. Vernadsky, Yalta. (in Russian)

7. Menshikova, E.R. 2017. "Mif kak natural"nyy obmen" [Myth as natural exchange], CredoNew, no 1, 2, 3. (in Russian)

8. Menshikova, E.R. 2009. "Muzykalnaya skrizhal" iskusstva: simfonizm kak khudozhestvennyy metod 20-kh." ["The Musical Tablet of Art: Symphony as an Artistic Method of the 20s."], Voprosy literatury [Literature issues], no. 4, pp. 167-190. (in Russian)

9. Menshikova, E.R. 2019. "The natural landscape of philosophy (Political reflection of Heraclitus and Aristotle)", Art Literature Scientific and Analytic Journal Burganov House. The Space of Culture, vol. 15, no, 4, pp. 24-42. DOI:10.36340/2071-6818-2019-15-4-24-42 (in English)

10. Menshikova, E.R. 2020. "Natural Landscape of Philosophy (Political Reflection of Heraclitus and Aristotle). Part II», Art Literature Scientific and Analytic Journal Burganov House. The Space of Culture, vol. 16, no. 1, pp. 56-79. DOI:10.36340/2071-6818-2020-16-1-56-79 (in English)
11. Menshikova, E.R. 2020. "Paradoks Izhetsa: vozmozhna li zhizn» vne Soznaniya, ili kritika formalnogo razuma" ["The Liar's Paradox: Is Life Outside of Consciousness Possible, or Criticism of Formal Reason"], CredoNew, no. 1, pp. 258-300. (in Russian)

12. Menshikova, E.R. 2011.«Protey, zateryannyy v sadu Gesperid, ili ekzistentsial'nyy skachok groteska kak antikrizisnaya model' i kak smyslosokhranyayushchiy printsip iskusstva» [«Proteus, lost in the garden of the Hesperides, or the existential leap of the grotesque as an anti-crisis model and as a meaning-preserving principle of art»], Art Literature Scientific and Analytic Journal Burganov House. The Space of Culture, - Москва, 2011. № 1. C. 8-22. (in Russian)

13. Menshikova, E.R. 2002. "Redutsirovannyy smekh Yuriya Oleshi"[" Reduced laughter by Yuri Olesha"], Voprosy filosofii [Philosophy questions], no.10, pp. 75-85. (in Russian)

14. Menshikova, E.R. 2019. "Rondo Mifa: «Troyanskiy terrorizm» kak ideya isklyuchitelnosti, ili summum bonum Tsezarya: nasilyem pokoryayte mir" ["Rondo Myth: «Trojan Terrorism» as the idea of exclusivity, or Caesar's summum bonum: conquer the world with violence"], Credo New, no. 2, pp. 348-377. (in Russian)

15. Menshikova, E.R. 2019. "Svinguyushcheye Soznaniye ili «samoorganizuyushchiysya Khaos» kak rezonansnaya sistema" ["Swinging Consciousness or «self-organizing Chaos» as a resonant system"], Credo New, no. 3, pp. 268-309. (in Russian)

16. Menshikova, E.R. 2015. Smekh Proteya: fenomen grotesknogo soznaniya [Proteus's laugh: the phenomenon of grotesque consciousness], p. 340 (in Russian)

17. Menshikova, E.R. 2019. "Smekh kak modern, ili reliktovoye izlucheniye menippei («Nevelskiy kruzhok filosofii» M. Bakhtina vs «Prokrida» O. Freydenberg)" ["Laughter as Art Nouveau, or the relict radiation of the menippea ("Nevel's Circle of Philosophy" by M. Bakhtin vs "Procrida" by O. Freudenberg)"], «Russkiy Logos-2: modern-granitsy kontrolya». Materialy mezhdunarodnoy Filosofskoy konferentsii «Russkiy Logos: gorizonty osmysleniya» ["Russian Logos-2: Modern-Borders of Control". Materials of the International Philosophical Conference "Russian Logos: Horizons of Comprehension'], vol.2, pp. 496-499, September, 25-28, Saint-Petersburg (in Russian) 
18. Menshikova, E.R. 2009. "Tragifars i dissipativnost» kak priznaki karnavalizovannogo soznaniya" ["Tragifars and dissipativity as signs of carnivalized consciousness"], Sakralnoye i sekulyarnoye $v$ russkoy kulture [Sacred and secular in Russian culture], Moscow (in Russian)

19. Menshikova, E.R. 2019. "Troyanskiy terrorizm kak printsipat Obmana, ili v ob"yatiyakh terrakotovoy saranchi (etimologicheskiye nadkrylya virtus)" ["Trojan Terrorism as a Principle of Deception, or in the Embrace of the Terracotta Locust (etymological elytra virtus)"], Credo New, 2018, no. 3-4, no. 1. (in Russian)

20. Menshikova, E.R. 2018. "Troyanskiy terrorizm kak ustanovlennyy poryadok (disciplina), ili kochuyushchiy kolonat (missiya Mifa v prostranstve T. Mora «Utopiya»)" ["Trojan terrorism as an established order (disciplina), or a nomadic colonate (mission of the Myth in T. Mora's space "Utopia")"], Credo New, 2018, no. 2, pp. 189-221. (in Russian)

21. Menshikova, E.R. 2018. "Troyanskiy terrorizm: usloviye evolyutsii ili mest kolonistov? (k probleme «svoy/chuzhoy»)" ["Trojan Terrorism: Evolution Condition or Colonist Revenge? (to the problem "friend / foe")"], Credo New, no. 1, pp. 183-214. (in Russian)

22. Menshikova, E.R. 2019. "Filosofiya Mifa vs naturfilosofy: monologi Gesioda kak pervoelementy sokraticheskikh dialogo" ["Philosophy of Myth vs natural philosophers: Hesiod's monologues as the primary elements of Socratic dialogues"], Pragmatika filosofskogo teksta: materialy Vserossiyskoy nauchnoy konferentsii «XV Tavricheskiye filosofskiye chteniya "Anakharsis» [Pragmatics of a Philosophical Text: Materials of the All-Russian Scientific Conference "XV Tauride Philosophical Readings" Anacharsis"], September, 16-19, Sudak, pp. 113-115. (in Russian)

23. Menshikova, E.R. 2019. "Filosofiya Smekha ili «grotesknoye soznaniye» kak plata za sushchestvovaniye" ["Philosophy of Laughter or "grotesque consciousness" as payment for existence"], «Russkiy Logos-2: modern-granitsy kontrolya». Materialy mezhdunarodnoy Filosofskoy konferentsii "Russkiy Logos: gorizonty osmysleniya» ["Russian Logos-2: Modern-Borders of Control". Materials of the International Philosophical Conference "Russian Logos: Horizons of Comprehension"], vol.2, pp. 173-182. (in Russian)

24. Menshikova, E.R. 2019. "Formula astrukturnosti Soznaniya: ot integrala doveriya i letuchikh fraktalov smysla k obretayemoy singulyarnosti" ["Formula of the astructurality of Consciousness: from the integral of trust and volatile fractals of meaning to the attained singularity"], Credo New, no. 4, pp. 277-311. (in Russian)

25. Menshikova, E.R. 2018. "The double axe of Troy: the mission of Myth as a nomadic colonatus or Procrustean space of being", XXXth International Conference of Philosophy "Polis, Cosmopolis and Globalisation" (SamosPythagorion: $20^{\text {th }}-26^{\text {th }}$ July 2018), Samos. (in English)

26. Menshikova, E.R. 2017. "Laughing Scaffold of Perception or Antiworlds of Crying Lira: how and why "grotesque Consciousness works", TSC'2017 THE SCIENCE
OF CONSCIOUSNESS, June 5-10, 2017. La Jolla, California. (in English)

27. Menshikova, E.R. 2018. "Laughing scaffold perception or antiworlds crying lira: how and why "grotesque consciousness" works", International Journal of Cultural Heritage, no. 3, pp. 11-37 (in English)

28. Menshikova, E.R. 2020. "Metaphor - a volatile quantum of Meaning, or formula of structuredness of Consciousness", TSC'2020 THE SCIENCE OF CONSCIOUSNESS, April 13-18, 2020. Tucson, Arizona (in English)

29. Menshikova, E.R. 2017. "The Natural Landscape of Philosophy (political reflaction of Heraclitus and Aristotle)", $29^{\text {th }}$ International Conference of Philosophy "Greek moral and political philosophy-From Pre-Socratics to Neo-Platonism" (July, 7-11, 2017), Rhodes. (in English)

30. Menshikova, E.R. 2018. "The Natural Landscape of Philosophy (The Political Reflection of Heraclitus and Aristotle)", Philosophy Study, vol. 8, no.1. (in English)

31. Menshikova, E.R. 2019. "Quasars of Introjection, or as Consciousness Swings", TSC'2019 THE SCIENCE OF CONSCIOUSNESS. June 25-28, 2019, Interlaken, Switzerland, Collegium Helveticum Zurich, p. 266. (in English)

32. Menshikova, E.R. 2016. "Singularity Laugh or Grotesque Consciousness in Relation to Aristotle's Poetics», XXIV World Congress of Philosophy "The Philosophy of Aristotle", Athens 09-15 July, University of Athens, School of Philosophy University Campus, Zografas. (in English)

33. Menshikova, E.R. 2019. "Swinging Consciousness, or Self-organizing Chaos as a Resonant System", Philosophy Study, vol. 9, no. 1. (in English)

34. Menshikova, E.R. 2018. "The Trojan Terrorism as an Established Order (Disciplina), or the Nomadic Colonatus (Mission of Mith in the space of Sir Thomas More's "Utopia")", International Relations and Diplomacy, February 2018, vol. 6, no. 2. (in English)

35. Menshikova, E.R. 2019. "Trojan Terrorism as a Principate of Deception, Or in the Arms of the Terracotta Locust (Ethymological Wing Cases of Virtus). Part I.", International Relations and Diplomacy, November 2019, vol. 7, no. 11. (in English)

36. Botvinnik, M.N., Kogan, B.M., Rabinovich, M.B., \& Seletsky, B.P. 1985. Mythological dictionary, p. 176, Moscow (in Russian)

37. Dictionary of literary terms. 1974. (in Russian)

38. Freidenberg, O.M. 1998. Mif i literatura drevnosti [Mif $i$ literatura drevnosti], p. 800, Moscow. (in Russian)

39. Freidenberg, O. M. 1998. "Obraz i ponyatiye " ["Image and concept"], Mif i literatura drevnosti [Ancient myth and literature], pp. 223-622, Moscow. (in Russian)

40. Freidenberg, O. M. 1997. Poetika syuzheta i zhanra [Poetics of plot and genre], Moscow, p. 448 (in Russian)

41. Pyatigorskiy, A. 2007. What this a political philosophy: thinkings and considerations, Moscow. (in Russian) 


\section{DOUBLE AXE МИФА (ДИФТОНГ ЗОНГА)': ЗАБЫТАЯ ФЛЕЙТА ГРЕЧЕСКОЙ ЭПИГРАММЫ/ ОПРАВДАНИЕ ПОДЛОСТИ, ИЛИ ТОТАЛЬНАЯ ТРАНСФОРМАЦИЯ «ПО ФАРЕНГЕЙТУ» (ПАРАДОКС ЦИНИКА)}

\section{1. ЗАБЫТАЯ ФЛЕЙТА ГРЕЧЕСКОЙ ЭПИГРАММЫ (ЧАСТЬ 1)}

\begin{abstract}
Аннотация. Пока философы и поэты прозревают свое настоящее, их оставленное современникам и потомкам «восприятие» медленно и не сразу начинает восприниматься, и пока его начнут 'распаковывать' и оно будет воспринято (и вероятно не так, как на то рассчитывал автор), и когда его начнут слышать гласом вновь заговорившей Кассандры, пройдут года, если не столетия, - и оттого важно понимать, что философы и поэты всегда прозревают свое настоящее, в надежде понять прошлое, без которого просто невозможно пробудить ни собственное Сознание, ни вечно впадающее в спячку общество, которое едва проснувшись, хватается за кистень, при этом будущее их вообще не волнует, поскольку оно существует только в воображении, и которое ускользает, по мере приближения к нему. ${ }^{2}$ Но само
\end{abstract}

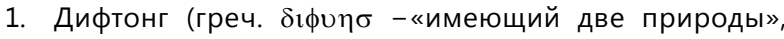
«двойной образ») - сложный гласный звук, состоящий из двух элементов, образующих один слог, дарующий фонетическую целостность. Зонг - песни-речитативы, которые ввёл в свою драматургию Б. Брехт, используя аллюзию на древнегреческую трагедию, где Хору отводилось место «торжественной паузы осмысления», которая могла исполняться одним человеком, была аллегорична и служила своего рода «подсказкой» для формирования у зрителя Образа Понятия.

2. Возможно это метафорическое разрешение апории Зенона об Ахиллесе и черепахе, однако лучшую аналогию дарят русские Былины - образ-аллегорию Микулы Селяниновича, которого не мог догнать богатырь Святогор - ибо время догнать нельзя, только когда оно само остановится. Мы были свидетелями такой остановки - сколько Святогоров выявило «зависание времени» во всемирной самоизоляции? Может перевелись - укоротились? 'прозревание' многие склонны соотнести с будущим как с «процессом воображаемой перспективы», и только на том основании, что его скользнувшее фантастической каплей иносказание легче было бы соотнести с чем угодно, только не с тем временем, в котором оно задумывалось, писалось и осуществилось как литературное произведение. Словно незримый Создатель из ноосферы разводит по разным углам ринга Восприятие и Иносказание, чтобы первое как бы поднабрало в весе, а второе - над техникой своей поработало, чтобы свинг как 'резонансная интродукция' произошел бы, как можно позже, но был чётким и метким, и всеобъемлющим, неся в себе такую мощную звуковую волну, что шелковичные черви, семенящие к Великой Китайской Стене, обращались тутовой бабочкой также стремительно, как может 'пронзить прозрение', также быстро, как прозревает чужое восприятие в вас ваше же «наитие», что дремало и мешкало с выходом, заставляя искать новые слова, метафоры и выражения. Процесс «постижения ускользающим иносказанием» включается актом доброй воли собственного Сознания, что одним прекрасным или хмурым утром удивится самому себе, и оказывается следствием парадоксальности ума, что мы называем сингулярностью Сознания. И такое 'ускользающее восприятие' кидает вам, вглядываясь стрекозиными фасетками, греческая эпиграмма, автор которой, придумав эту саму пучеглазую метафору, рождая Образ Понятия, заставлял читающего ритмические строчки встрепенуться рассудком - и обрести или вспомнить нравственные принципы, наполняя здравым смыслом или весёлым парадоксом, что позитивны, своё существование, вдруг просияв 
осознанием, соорудив себе шпаргалку восприятий на все случаи жизни из противоречий, явленных стихом. Так терапевтически греческая эпиграмма могла воздействовать, если ее иносказание ловили.

Мысль, как лотос, - всегда в потенции раскрытия, всегда в сложении себя из лепестков света прозрачных синекрылий, что без тени не видны и не сиятельны - и потому, всякая мысль двояка, неся свою «тень» в кармашке представления, как не противоречащее противопоставление. Лотос приобретает силу волшебства только на темной глади пруда или на изумрудном чашелистике своём, что непрозрачен тёмной умброй, а $\mu \mu \beta \rho \alpha$ с греческого - это «тень», что всегда имеет полутона, но как сумрак ночи отождествляется с «таинственным» и «тайным», что всегда соотносится с мышлением - умственным восприятием зримого и ощущаемого, ибо способно «видеть», а ночью мы именно »видим» - не только ощущаем зрачками глаз, но обращаем их внутрь себя, то есть начинаем мыслить внутри себя: зрительные впечатления обращая в языковые конструкции, ибо мыслим мы посредством слов, ззримое» переводя тропической тропой - вереницей тропов - в структуру языка, мыслепредставления преобразуя в предикат Идеи - словесный образ. Полисемия (многозначность), не лишая речь стремительной иноходи, а с нею ясности и певучести (свойство носителя определённой языковой традиции) изложения - того потока струйного смыслов, что гению прозрения отворяет двери, обрекает блуждать в потёмках собственного сознания, пока вы не запасётесь корзинкой желудей (словами) - собственным языком выражения, что позволит взмахом манты погрузиться в океан понимания, чтобы легко и просто высаживая метафоры, видеть, как стремительно идут всходы восприятия и как смысловая дубрава уже радует великодушием своей мощи. Метафора помогает мыслить, а приучаясь мыслить метафорически, мы легче ловим смыслы - улавливая ресничками, приманивая, словно синичек, зерном образных облаток, - рассаживая этих синеок пестрокрылым покрывалом на своём окне, что, отворяя вам мір, вместе со Светом всегда впускает Нечто.

И если Платон помышлял «высшее благо» как «совершенство», что упорядочено и оформлено, при существующей стойкой оппозиции «блага» - «злу», что абсолютно бесформенно и неупоря-
Ключевые слова: метафора, греческая эпиграмма, «ускользающее иносказание», восприятие, Сознание, Образ Понятия, эйдос, Образ Представления.

доченно (словно паника, добавим, что хаотична), то Аристотель и перипатетики рассматривали эту «неоформленность» как «отсутствие добра»

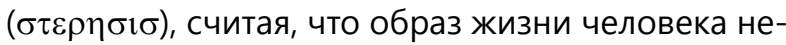
посредственно влияет на самого человека, его сознание, характер, порой ограничивая понимание, создавая соотношение между поступками и переживаниями (рефлексиями), а потому «зло» (порок) можно избежать, если воспитывать характер (разум) посредством регулярного совершенствования и заботы - опрыскивать ${ }^{1}$ во избежание заболеваний. И предваряя профилактические действия, необходимо было проговорить это «отрицание добра» - люстрируя порочный характер, выставляя его «типичным объектом» города или деревни (собственно полисного мира), «типическим» объявляя негативные проявления субъекта права, что не знает «доброе» («добродетельное»), но оправдывает своё «злое» (порок ума и сердца, выражаемый образом жизни) правом частной жизни. Феофраст, заложив основы психоанализа,

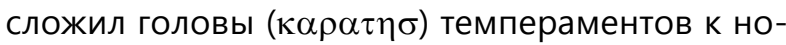
гам социума - полагаясь на откровенный диалог и ощущая свою ответственность как глава философской школы (по сути, верховный жрец эпохи зарождающегося упадка). Добавим, греческая эпиграмма всегда шла этим фарватером, откликаясь по зову Сознания: сохранить мышление в языке, восполняя несовершенство человеческой натуры, наставляя несовершенный разум разуметь - совершать мыслительно-образные операции, складывая Образ понятия из предъявляемых посылок, прибегая к ироничному скетчу или сатирическому обобщению.

Двуединство представлений древних греков приучает их не только к нестабильным системам: к революциям, полисной организации, смеху, но и создаёт прецедент в культуре - двойственную

1. Стагирит после того, как покинул Афины, увлёкся растениеводством - интерес к метафизике перешёл в практические опыты, что отразилось в ряде сочинений, посвящённых животным и растениям: История животных, О частях животных, О растениях (что утрачено, но существует 9 ссылок-упоминаний на это сочинение). А чем ещё заниматься философу в изгнании, как не собственно жизнью, наставляя и пестуя, пусть и других, хотя бы и растений? 
модель искусства. Принцип «гротесков»: переходить из одного тела (ипостаси) в другое - покоится на трех китах противоречивого мышления древних греков. Это их Протей, в котором стоики видели аллегорию материи, что формировалась и оформляется самой богиней форм - Эйдотеей. Такое аллегорическое мышление могло сформироваться только Мифом и благодаря Мифу - этой колыбели политической рефлексии человека ${ }^{1}$, и только получив в наперсники Протея, подчинённое Посейдону морское божество, обладавшее способностью принимать любой облик, предсказывая будущее, и явившееся символом многоликости и многообразия, и его дочь Эйдотею. ${ }^{2}$ Именно она подсказала Менелаю пути возвращения на родину: схватить спящего Протея и не выпускать из рук какую бы форму тот ни принимал, пока не окажется в своём настоящем облике «старца» и не даст совет о возвращении в Спарту, и не раскроет судьбу героев Троянской битвы, - то есть предложила «форму» исполнения желания: материализуя словом, способствовала осуществиться предсказанному и задуманному, и тем самым структурировала материю (и мысли в том числе, что материальна «вопреки»), формализуя буквально: направляя и организуя. Оборотничество морского божества принималось за норму, тогда как «бесповоротность», означавшую закон предопределённости, изначальной заданности, грек классической эпохи стремился не только избежать, но осмеять. Эйдотея как порождение «материи» структурирует сознание, форматируя мышление буквально: лексикой языка, синтаксисом (организованным движением слов) и метафорой, помогая мыслить, ибо ду-

маем мы словами. Заметим, такая слившаяся в танце двойная звезда Протей-Эйдотея всегда взыскует формы выражения, и особенно мысли,

1. Подробно о термине «политическая рефлексия» в моих статьях «Миф как натуральный обмен» и «Натуральный ландшафт философии» [7, 9]; его суть кратко: это мышление человека, что само себя мыслит, отвергая предыдущее как ложное или неполное, подвергая сомнению, словно змея скидывая кожу, и тем самым продвигаясь на длину собственного тела, - и с этого «первого шага» начинается политическая свобода человека, которая обеспечит ему институализацию, сформировав политическую (гражданскую) стратегию и образ жизни. Русский философ А. Пятигорский «политической рефлексией» называл "мышление, направленное на политическую философию государства".

2. Образ Протея в литературе используется для обозначения суперпревосходства в чем-то, либо вносит аллегорический аспект при описании качества чего или кого-либо («И слог его уступчивый и гибкий, / Живой Протей, все измененья брал». Вяземский П. А. О Пушкине.) [36, С. 125]. и будет вечно таять раскаяньем заката, маня совершенством красоты и гармонии, как розопёрый лотос - рождающий образ солнца, Смысла, что как ветреник, будет тяготеть к скольжению, однако окажется вечно ускользающей Галатеей, которую заклинают либо проклиная бегут, теряя совершенство форм, линий и лепестки ума. Таким образом ситуация с мышлением (читай, Сознанием) остаётся в сатурналиевских объятиях Протея, чья морфология зыбка, но закольцована текучестью постоянных трансформаций и представлений.

Ольга Фрейденберг ${ }^{3}$ утверждала, что «античная литература еще вся в процессе становления», и что было бы абсолютной ошибкой рассматривать ее «как нечто готовое по своей форме, как нечто само собой разумеющееся, давно знакомое» [39, С. 229]. Как «философ, не осознающий себя в этом качестве» (Н. Брагинская) [38, С. 750], Фрейденберг подарила мировой науке глубокие описания сознания, действуя по-протеевски и прибегая к искусности Эйдотеи: аллегорически, сталкивая противоположные смыслы в границах одного слова, осмысляя культурологически литературу древнего мира, и, считая «материю насквозь духовной, а дух выраженным в материи» [38, С. 750], видела в ней возможно именно танцующуюся пару Протей-Эйдотея ${ }^{4}$ - ту вечно меняющуюся материю, всегда кружащуюся и оформляющуюся. По нашему разумению, такое описание мышления (мировоззрения), что обрушивалось на читателя потоком фактического материала из ее книги, следует назвать «второрождением ${ }^{5}$, поскольку оно давалось через культуру, что виделась Фрейденберг «частью природы и мироздания» [38, С. 750], предъявляя и предлагая совершенно возрожденческий принцип «видения», практически натурфилософский, что объял философию классической Древней Греции, впуская мироощущения других культур, но еще и потому, что этот принцип «объяснения», будучи философской интерпретацией, анализировал произведения искусства, что уже были «отраженным восприятием» бытия-в-мире, человека

3. Фрейденберг Ольга Михайловна (1890-1955) - выдающийся советский филолог и мыслитель.

4. По одной из версий мифа Эйдотея - супруга Протея.

5. Именно так: второрождением, благодаря открытию Гутенберга, в Европу из «восточного плена» стала возвращаться античная мысль - через переводы с греч. на латынь и книгопечатанием, то есть «массовым», для конца XV в., тиражированием трудов древнегреческих философов, риторов, географов, историков, писателей и поэтов. 
в нем, и космоса силою воображения и мысли других и многих, были уже «преломлением»в искусстве - Образом представления.

\section{ВЕЛИКОЕ РАССЕЯНИЕ СМЕХОСОФИИ}

В Греции обобщением занималась философия, но и в изящной словесности ему тоже нашелся уголок - в греческой эпиграмме, следы которой сохранились с VII века до н. э., где можно обнаружить впаянные в речь оттиски «сатирического». В Риме действенным обобщением стала, сатира, но Рим, а это уже I век до н. э., наследуя Греции и вбирая ее культуру и искусство вместе с пространством и народонаселением в свои имперские границы, оказывался в рамках того критического самосознания, что завещали греческие философские школы (открытые в разных точках метрополии), обогатив его широким иллюстративным материалом в духе гротесков Гойи - еще не рожденного, и поэтической сатирой. «Осмеяние» как 'вид обобщающего мышления' древнего грека (того совокупного «грека» как представителя греческой цивилизации) спустя три тысячи лет мы можем уловить в чудом сохранившихся артефактах, рассыпанных по островным музеям современной Греции - в керамической скульптуре (миниатюре) гротескного изображения (Самос, Родос), гротескной вазописи (практически везде), настенной живописи (фрески Акротири), и особенно в греческой эпиграмме. Современное значение слова «эпиграмма» несколько не совпадает с первоначальным своим денотатом, что означал буквально «надпись», являясь собственно надписью на надгробных камнях (эпитафии) или на статуях, треножниках и других предметах, приносимых в дар божеству (посвящения), и что были кратки и писались в стихотворной форме, преимущественно гекзаметром. ${ }^{1}$ Вот пример одной из древнейших:

«Много ворон на утесе смоковница кормит плодами; всех Пасифила гостей, добрая, рада принять» [2, С. 5].

Это написанная на смерть гетеры Пасифилы эпиграмма Архилоха, жившего в VII в. до н. э., почитавшегося наравне с Гомером, считавшегося «отцом сатиры и ямба», одного из основателей греческого стихосложения (что без обобщений не работает(!) и невозможно), изо-

1. См.: Греческие эпиграммы (VII век до н. э. - IX век н. э.). Перевод, статья и примечания Л. В. Блуменау. - Москва-Ленинград ACADEMIA, 1935. - с. 316. C. XV. бретателя «архилоховых стихов», в кратости которых отражалась мудрость понимания, и что, являя потомкам сохранившийся образец первой эпиграммы-сатиры, как шепот стрекозы дарит восприятие человеческого существования, что не было однозначно «плохим» или «хорошим». Гетера как 'смоковница' 2, что утоляет и вскармливает по доброте натуры (и при этом берет деньги за услуги) всякого, кто одиноким вороном или вороной оказывается поблизости, и сама предельно одинока: одна да на утёсе - и всем видна ее кривизна да изломанность веток, но ее приветливость, даруя «пользу» другим, служит ей и осмеянием и осмыслением - ee modus vivendi (гетера - статус «социально сниженной ответственности») всегда будет амбивалентен, с двойным дном, и подаваться в сатирическом освещении. И здесь Смех «работает» на метафоре - через иносказание, что «преувеличение» обращает в Образ Щедрости, что научилась извлекать пользу из той «пользы» (направленного блага), что оказывает другим. Архилох как Протей сатирического ямба двустишием прозрачных крыл именно нашептал дифирамб о проказе (как «шалости») мира - проституции, что была и остаётся проказой на теле общества, угнетая порочным кругом безответственности. И здесь мы оппонируем самой Ольге Михайловне, что не видела сатиру в Греции, но она была, и была почитаема как смоковница, или гетера, ибо сияла сверкая на самых видных и значимых местах социума - меткой памятника/святилища, метательным копьём Смысла, то есть была распространена как "обобщающее мышление", предназначенное для многих как совокупное высказывание о частном, что носит или имеет обобщающие черты. Так и эпиграмма Анакреонта:

«Мужествен был Тимокрит, схороненный под этой плитою. Видно, не храбрых Арей, а малодушных щадит» [2, С. 10] - как «эпитафия воинам» передает не только скептицизм бывшего воина, но и его сарказм: на войне только трус и выживет, и который делится своим пониманием несправедливости мира - от смеющихся Мойр, что

2. Субтропическое дерево, сильно искривлённое с раскидистой кроной и густой листвой, дающей много тени, с обилием сладких и питательных плодов, насыщенных полезными микроэлементами, с пористой древесиной, заменяющей топливо, что почиталось у древних наравне с оливой, считаясь «райским», символизируя Божие благословение (Библия), здоровье (Коран), олицетворяло мир и процветание. 
не мстят, а метят, пощады не жди, вручая читающему свое осмысление тех случаев жизненных перипетий, что вопреки соблюдению нравственных правил и проявленной доблести оказываются обычны своей закономерностью поражения, что отнимают жизнь у праведника - даруя подлецу, и эта горькая усмешка, что, используя обратный порядок слов, и создаёт то «отрицание», в котором оставлена заветная игла - мыслительное обобщение. И как Кощеево наследство оно оставлено Тем, кто был в эпицентре политических событий века, словно укушенный ядом стратег, постигший коварство мира, кто провёл свои молодые годы при дворе тирана Поликрата Самосского ${ }^{1}$, создавшего гигантский (для того времени) военный флот, построивший первый подземный акведук ${ }^{2}$, что «разорял без разбора земли друзей и врагов» (Her., III, 39), превративший Самос в крупнейшую морскую и торговую державу середины VI в. до н. э. простым и наилегчайшим образом - 'стилом' пиратства ${ }^{3}$, и снискавшего славу как отважный строитель (его акведук построен до Евклида и его геометрии, но по всем правилам: его готические своды не рухнули, вода продолжает течь, функционируя как километровый тоннель на восьмиметровой глубине по сегодняшний день). При таком господине сложно пребывать в ипостаси «лирического поэта» - именно эпиграммы выдают Анакреонта как умудрённого превратностями жизни язвительного циника -

1. Анакреонт (сер. VI в. до н. э., Теос (Иония) - прожил около 85 лет, Абдера (ионическая колония на фракийском побережье)) - ионийский лирик, проведший свои лучшие годы при дворе Поликрата (574 - 522 г. до н. э.) - удачливый пират, что наследовал власть от отца-пирата (то есть захватившего остров), создавший флотилию из стовесельных кораблей, охранявших бассейн Эгейского моря с прилегающими морскими путями и путинами, но еще более пополнявших казну тирана набегами и разбоем, о котором начинает свое повествование не только Геродот, но и Фукидид, но и заботящийся об экономике региона (открытие шерстяных мануфактур на фоне развития животноводства), расширение торговли (собственные чеканные монеты) и инфраструктуры (подземный акведук, мост, дороги и храмы, городская архитектура и проч.); а после его смерти перебрался в Афины к Гиппарху (ум. в 514 г. до н. э.) - тирану с 527 г. до н. э.

2. Подземный акведук, строившийся около двадцати лет, служил и «бомбоубежищем» древних, являясь своего рода первой веткой «самосского метро» - двойной тоннель: для воды (нижний ток) и для людей (верхняя дорога, где человек может идти не сгибаясь).

3. Самое распространённое оружие Средиземноморья двойной ахе (небольшой топорик с бронзовым наконечником из двустороннего тесака) - оружие рукопашного боя, чьи редкие экземпляры, датируемые XI или IX вв. до н. э., можно встретить в Британском музее, и даже в музеях Самоса. ямбического Терсита, который, жизнь пройдя до половины, вдруг очутившись в сумрачном лесу (полагаю, время написания совпало с периодом смерти Поликрата или с периодом «после»), сумел сориентироваться на местности и ... сменить покровителя - на Гиппарха, переехав в Афины. Сама жизнь, полная военных баталий, обманов и каверз, служила обоснованием для его модуса существования - Эзопова сверчка при дворе короля, что храбростью был не в Артура, но едкой насмешкой владел виртуозно.

«Дальше паси свое стадо, пастух, - чтобы телку Мирона, как живую, тебе с прочим скотом не угнать» (На бронзовую телку Мирона) [2, С. 11] - это эпитафия костям украденной коровы (видимо, бутафорским, ибо та была украдена), что перемежается с издёвкой над нерадивым хозяином, который, зная о пиратах, не беспокоится о сохранности своего стада, но ставит ей бронзовую статую (что не разумно и не практично) - и в таком случае, эпиграмма Анакреонта, перекликаясь с «поучениями» Гесиода в «Трудах и Днях», что 'философским обобщением' вводил уложение правил обыденной жизни, наставляя быть рачительным хозяином и деятельным человеком, вдруг пролетала двукрылой егозой (двустишием) - настраивая ехидной усмешкой о несовершенстве человеческой натуры на критический лад, высмеивая тщеславие богача и его «крокодиловы слезы». Так бронзовая корова, врастая в могильный камень, оказывается 'символом лицемерия и глупости', являя Образ понятия. На примере Анакреонта заметно, что образ жизни и покровители в значительной степени влияли на творческую Музу этого поэта, имевшего склонность к басне, умевшего отличать зерна от плевел, но вошедшего в историю как автор эротической лирики, что изменит жизненный стиль на «гедонизм», и, вопреки популярному credo «пиратства», что культивировалось век от века, и вошедшему в моду «насилию», смело заявит:

«Мил мне не тот, кто, пируя за полною чашею, речи только о тяжбах ведёт да о прискорбной войне; мил мне, кто, муз и Киприды благие дары сочетая, правилом ставит себе быть веселее в пиру» [2, С. 11].

Здесь анафорическое отрицание вводится иронией, причем, горькой, то 'мыслительное обобщение' о реальном для поэта Анакреонта бытии-в-мире, что напоено тщеславием и лицедейством, и только силою ума и стремлением к 
гармонии (что осуществимо лишь через искусство) возможно выбраться из ложных представлений о мире и космосе, из плена порочных иллюзий и заблуждений, находя Смысл в служении музам. Афинский тиран оказался полной противоположностью тирана Самоса - муз предпочитая насилию, искусством заменив клинок, превратив свою жизнь в любовный досуг, но потерявший уважение граждан и трон за свое миролюбие, то есть будучи пацифистом - за бесконфликтность и нестяжательство. Однако такое «понимание» доступно лишь тому, кто, не меняя статуса придворного поэта - оруженосца рифм, и по совместительству шута, постигнет амбивалентность самой жизни - в бою и на пиру, приняв обе позиции как две стороны одной медали, испытав две «рутины» сочлененья, и лаконизмом дифирамба закрепив истину, что была в вине, виновницей всех бед сочтя войну. А потому поэт, слагавший эпиграммы и считавший ритмы собственного сердца, и аритмию эпохи видевший невооружённым глазом, был философом, что говорил с этой эпохой языком сатирического дифирамба, точнее, его пророщенным зерном.

\section{ДАКТИЛИЧЕСКАЯ АФФИРМАЦИЯ СМЫСЛА}

Заметим, мы трактуем греческую эпиграмму не периода расцвета римской сатиры (I век до н. э. - І век н. э.), но поры, когда Рим не был не только 'империей', но лишь начинал свои модуляции по захвату чужих территорий, играя в адаптацию «Terra Священного Рима». Элегическое двустишие, в котором гексаметр (шесть стоп) первого стиха заменён пентаметром (пять стоп) путём усечения третьей и шестой стоп - так называемый дактилический ямб, придавая стихотворению определённую законченность, что не требовала «продолжения», как гексаметр, но просодически уравновешивая долгие и краткие слоги в стихе, разбивая на две равные (по 2,5 дактилической стопы) части цезурой, - своим кратким суждением, или словесной формулой, которая при многократном повторении (а эпиграммы прочитывали не раз и декламировали, где только можно, передавая и перенося 'содержание' от места начертания (святилище, могила) по городам и весям на вербальной ладье говорящего) закрепляло возникаемый Образ представления о предмете, которому была посвящена эпиграмма, и, работая на укрепление и установку этого представления в сознании (собственном - для говорящего, и чужом - для воспринимающих на слух), способствовало возникновению (или сложению из «картинок» мыслительно-визуальных представлений) того Образа понятия предмета или явления, что и оказывался мыслительным обобщением совокупным представлением 'понимания', что принималось многими по объективным причинам: совпадением ощущений, восприятий. Так ритмически организуется мысль, чтобы рифма приобретала характер философского афоризма, что запоминался бы сам собой благодаря музыкальному ритму ударений (просодии) ${ }^{1}$, заворачивая смысл в лакричную обёртку лаконичной фразы, становясь своего рода аффирмацией² постижения. И поскольку всякая эпиграмма имела своего автора, будучи 'субъективной аффирмацией', она превращалась в сатирическое обобщение мыслеобразами (иногда саркастичное, порой скептичное), что прозревающее даль Сознание, или Провидение - та Эйдотея в паре с Протеем - оформляло 'понимание' ироничным иносказанием - метафорическим парафразом, в котором многозначность слова имела наипервейшее значение как способность и склонность не только к неологизму, смысловой полифоничности, но как возможность 'маевтической яви' - воспроизводством мысли, создавая прецедент рождения 'Образа понятия' посредством обертонов Смеха, что становился миропониманием и системой взглядов раз и навсегда. Полисемия (предрасположенность слова к многозначности) - верный шанс «понести»: забеременеть метафорически - возможность наполниться метафорами, или различными бликами и отражениями Смысла, причем в смежных проекциях и с иными фильтрами. И это не столько страдательный залог, но залог долголетия Образа понятия, что рождается из метафоры и метафорой - перехо-

1. Просодия (от греч. $\pi \rho о \sigma o \delta เ \alpha$ - букв. «припев», «ударение») - исторический раздел античной грамматики, посвященный ударению (первоначально музыкальному), а также долготе и краткости слогов. В 18-19 вв. Просодией называли совокупность правил стихосложения [36, С. 298]. В современном понимании термин отождествляют с понятием «ритмики», и применяют для обозначения элементов языка, на которых строится та или иная система стихосложения, то есть используется как «структурное обобщение».

2. Affirmatio, onis - «утверждение», «уверение», что поддерживает что-либо (напр., надежду, веру), подкрепляя и скрепляя восприятие [4, С. 24]. 
дом хода: от тропа к тропу ${ }^{1}$ - метонимическим сбором урожайности значений.

Смех греческой эпиграммы - это зимний Солнцеворот: в нем боролась стужа со светом, горе находило разумное объяснение случившемуся - через поворот-коловорот, поворотом Смеха осуществлялось осмысление: аналогично переходу хода через иносказание - ту художественную тропу «тропа», что высвобождала мысль, что была обречена на жизнь (как неминуемый приход весны после зимы), на свет - потому эти ранние смеховые формы называют люстрационными ${ }^{2}$ - светлыми, освобождавшими от уныния, страха, горя, тягостных дум и сомнений. И это все мыслительные операции, на которые была ориентирована древняя мысль (как продукт ума ничем не отличимая от современной, заметим), и которыми оперировала натурфилософия, чьи гамма-лучи растворены в Мифе, и как расходящиеся круги по воде они присутствуют в нем образами представлений, наделяя пониманием об устройстве мира, знанием взаимообусловленностей - связка ключей детерминантов ${ }^{3}$ рано или поздно оказывается на поясе у каждого, и тогда силы природы (фvбıб), становясь ближе как антропоморфные боги, оказываются понятнее через эту метонимичную замочную скважину, в которую приучаются смотреть с детства, раскрывая логику 'поступка' (или проявления) того действия или явления, что тяготея к абстракции, обернётся Понятием, поскольку наши антропологические сиамцы (психологическая и телесная неустойчивость), вызывая насмешку в ходе раскручивания (рассказывания) сюжетной нити того

1. Троп (от греч. тролоб - «оборот») - употребление слова в переносном (не прямом) его значении при помощи вторичных смысловых оттенков и уже непосредственно не связанных с его основным значением. Соотнесение значений слова (прямое и переносное) основывается на сходстве сопоставляемых явлений, или на контрасте, или на их смежности. Основные виды тропов: метафора (сходство и контраст), метонимия (смежность), синекдоха (соотношение части и целого), эпитет, сравнение, литота, гипербола, ирония [36, С. 427]. Троп представляет собой общее явление языка, чрезвычайно расширяющее его возможности понимания, раздвигающее границы словоупотребления - собственно речевой ландшафт, углубляя представление и восприятие явлений или предметов.

2. Lustro, avi, atum, are - I) освещать, 1) соб: о солнце; 2) пер: а) осматривать, разсматривать и умом разсматривать= взвешивать, обдумывать; б) проходить, обходить, объезжать, подвергаться; II) 1) делать светлым, 2) очищать приношением очистительной жертвы, освящать [4, С. 372].

3. Детерминант (лат. determino, determatum - «ограничивать, определять») - мат. определитель, выражение, составленное из элементов матрицы; с помощью детерминанта находятся решения линейных систем уравнений [3, С. 157]. или иного Мифа, представая в неблаговидной (с точки зрения Агона и этоса) ситуации, вручали шифр к детерминанту: границам дозволенного и недопустимого, помогая решать сложнейшие задачи самосохранения и жизнеобеспечения. Вся наша жизнь состоит из решения таких уравнений - система плутовских ходов (комбинаций) по разлинованной сетке координат, в смешении линейных и нелинейных заданий осуществляется Жизнь (на примере жизненных перипетий Геракла или Гермеса можно отследить, как один предпочитал линейность, претерпевая за свою честь и честность, а другой прибегал к нестандартным решениям - и выигрывал, но обманом, став покровителем воров (плутов), создатель лиры, оглашённый вестником полутонов, - оба сыны божьи, Зевесово семя, но различных жизненных установок). Посредством Смеха (осмеянием сакрального) человек возвращал себя к свету - на просвет осмысления, освобождаясь от пут заблуждений (мыслительных блужданий), так и от порицаний (догматических страхов), проходя Солнцеворот Смеха - ворота остужения и просветления, при этом ведя за собой все человечество. Люстрация (очищение) как обряд жертвоприношения связана с тризной, поминками, жертвой, которую воздают уже схоронив, осмысляя прожитое существование умершего (modus vivendi), при этом оплакивают захороненного, но вспоминают только положительное. Так же и в греческой эпиграмме, что поначалу предназначена была к люстрации предмета/объекта, укрытого могильным камнем, когда произнесением стиха-эпитафии, начертанном на том же камне, происходил сам обряд «очищения» - освящалась жертва путём освещения (мыслеобразным потоком), и тем самым она же очищалась от горя и стыда, пересмотром заблуждений и промахов, освобождалась от былых уже страхов и сомнений, но чужими глазами, как бы вмешательством «извне». И если римская сатира в литературоведческой науке давно и основательно укрепилась как 'люстрационный жанр', то и греческую эпиграмму также можно и должно соотнести с этим жанром только на том основании, что последняя предшествовала сатире и была ближе к философии, ибо являлась и строилась как 'помышляемое обобщение', что, подвергая обдумыванию, взвешенно - остранением - рассматривая на «просвет» разума осмысляемый предмет, выносило суждение, что освобождало от заблуждений, даруя прозре- 
ние как 'понимание' предмета/явления: человека ли, войны ли, космоса - оно осеняло (тут же над треножником или могилой) совокупным и объективным знанием о превратностях судьбы, поступках людей, несбалансированном и спонтанном бытии, готовя к принятию обстоятельств (схожих, что испытала «жертва») возможных и вероятных, постигая, именно минуя чужой Обман.

\section{2. ОПРАВДАНИЕ ПОДЛОСТИ, ИЛИ ТОТАЛЬНАЯ ТРАНСФОРМАЦИЯ «ПО ФАРЕНГЕЙТУ (ПАРАДОКС ЦИНИКА $)^{1}$}

Аннотация. Мифы переписываются, этосы корректируются в силу социально-политической нестабильности бытия, человек время от времени переформатируется, а гуманитарные науки продолжают отстаивать санитарные нормы и незыблемость своих фундаментальных границ. Открытия в геологии, биологии, астрофизике только последних пятидесяти лет раскрывают, подтверждая, крылатый постулат Гераклита о зыбкой переменчивости мира, его непостоянстве и текучести, но философы перестали подвергать сомнению истины, устоявшиеся до степени каменных истуканов с острова Пасхи. Отказываясь от нового взгляда на первоисточники, сканируя до кванта смысл - а не пролистывая словно гаджет, внимая и вслушиваясь в звучание возникающих параллелей, мы включаем 451

Достигать вершин истин «быстрым разумом невтонам» стало недосуг, ибо они практически все заняты по другому ведомству - рационализации и модернизации, занимаясь расширением и популяризацией матричных систем постмодернизма. Такая «технология» мыслительной деятельности, лишённая политической стратегии изначально, рисует унтер-офицерскую вдову, пристрастившуюся к субботним поркам, нежели атакующих несовершенства мира перипатетиков, поскольку молодые гуманитарии, не стесняясь, словно за ними стоит обезглавленная тень нигилиста Базарова, демонстрируют свою незрелость

1. Фрагмент книги, отправленной в печать, но само название было придумано в конце января 2020 для летней ежегодной философской конференции в Греции, и содержание данной небольшой статьи представляет собой расширенные тезисы для несостоявшейся научной экспедиции по причине Covid»19, и датируется маем 2020 г.

2. Метафора, что использует аллюзию на метафору Брэдбери «451 градус по Фаренгейту», из знаменитой его повести, и буквально означавшей температуру воспламенения бумаги, но ставшей символом сопротивления. градус по Фаренгейту², что грозит жаром арктического холода - не просто забвением культурной памяти, а невозможностью понять ошибки предшественников и смелостью их исправить. Такой «абсолютный нуль» вряд ли может свидетельствовать о расцвете культуры современной цивилизации, которой стало недосуг утешаться философией, поскольку вирус самости решительно вытесняет всякие сомнения и рефлексии, довольствуясь кратким курсом наспех составленных хрестоматий и клише рефератных пунктиров.

Ключевые слова: Сознание, Образ понятия, сингулярность, скрытая метафора, парадокс циника, Смысл, насилие, континуум, лицемерие, двоемыслие, формальный захват.

и неготовность к самостоятельному мышлению, иначе, к совершенствованию, а только клонированию ранее высказанного. Позволю вопросить как любящая тревожиться сомненьем: из чего складывается критерий «научности» сегодня? Неужели из количества ссылок на зарубежные работы (аналоговые, но далеко не тождественные смыслово и сутью)? Ужели числом чужих цитат можно убедить в 'научности' своих мыслей (и своих ли)? Как ее распознать/узреть средь расползающихся ужами иных речений, старанием школяра переписываемых скорописью? Словно цитатами стремятся залатать дыры на своей научной мантии? Возможно, беды в обществе оттого, что философы «кальдероновой арфе» послушны, и давно не стыдятся своих «прорех», словно все они Диогены, мучительно теснящиеся в скорлупке эго своего. При этом, ратуя за изменения в обществе, мыслители не готовы к пересмотру универсалий и концептов, видимо страшась признать фатальную константу самого человека, что на протяжении четырех тысячелетий остаётся упрямо устойчив в своих проявлениях инфантильности и само- 
сти. И по сути своей: упрощённой праздностью и всеобучем - человек 'общества потребления' ближе к кроманьонцу, чем к homo sapiens. 3aметим, эксплицитные утверждения о научном знании, о научных понятиях и теориях, апеллирующие постоянными (однажды и навсегда принятыми) терминами, что говорит о догматичности признанной раз и навсегда «истины», менее всего способствуют революционным прорывам в научной сфере, но провоцируют стагнацию от прогрессирующего склероза 'копировальной технологии и методологии'.

Рэй Брэдбери обыграл названием то «превращение», что происходило с родным ему обществом, его народом, и если Кафка свое восприятие антропологических изменений социума в 20-е гг. прошлого века представил довольно натуралистически: сюрреалистичным расподоблением в насекомое, то Брэдбери в 50-е изобретает отвлечённую метафору - 'огонь по Фаренгейту'. И если придерживаться цифры, что вынесена в заглавие, то она соответствует 232 градусам по Цельсию (привычной для русского и европейца температурной шкалы), а это не только температура «воспламенения бумаги», но и самовоспламенения сырой нефти (226-246) и торфа (225)․․ А если Брэдбери имел ввиду последнее? Торфяники горят долго, скрыто, глубинно и тушить их не то что бесполезно, но мучительно трудно, и тогда 451 - это не «горение», а тление, и в таком случае, он оказался предельно точен и выразителен - он изобразил тление человеческой породы - не смерть, но «смердение», ибо, повторим, основной смысл романа - это трансформация смыслов, а не буквальное сжигание книг, и человечество убьёт хлад расчеловечивания. Считаем, что писателя в первую очередь волновало растекание гарью порочное бытоустройство растущего города, ущемлённости в нем Сознания, которое лишали самобытности и самостоятельности, принуждая к играм с совестью, честью и разумом, манкуртизируя и тем самым расподобляя, оставляя вне закона - Духа предков, что обязан быть внутри каждого априори.

При этом замечу, возникшая ещё во времена Александра Македонского идея «глобализма», переосмысленная в цветных революциях XX века,

1. Согласно школьной таблице, и по ней же температура горения спички или пламени составляет 700-800 градусов. спрыснутая соком цветов хиппи², по сути своей, несла в себе дух социализма, и потому Европа и США сейчас пропитаны коммунистическими идеями анархического бунта, и это же можно рассматривать как следствие долгого сдерживания и запустения: маккартизм опошлил человека, ограничивая контролем и запретами, циркулярами лицемерия, ханжеством Капитала - и теперь Эйдосу нужна площадка рождения, вновь, - это закон сохранения энергии, или закон жизни по Гераклиту: из борьбы противоположностей творится новое как Демон противоречия, истинное или нет, пока не ясно, главное 'новое', однако, именно кажущееся «новым» оказывается забытым «прежним», латанным и перелицованным историческим тряпьём. ${ }^{3}$ Ведь «451 градус по Фаренгейту» это ещё и символ непримиримого мужества, а перевод в другую температурную шкалу, что каждый читающий неамериканец неосознанно совершает в своей голове всякий раз, как видит сноску «Фаренгейт», оказывается 'призывом вернуть трансформированные смыслы', утрачиваемые изподволь или поруганные внезапно, стёртые и забытые, как тот денотат «пожарного», что из «тушителя огня» превратился в «поджигателя». Самое время, чтобы вернуть утраченный смысл слову «тушить»! Уйти от произошедшей или происходящей трансформации смыслов (на полную противоположность) в момент и мигом, одним махом избавившись, невозможно, как сложно

2. Молодёжное движение, зародившееся в зарубежной музыкальной рок-среде вследствие распространения идей американского экзистенциализма в конце 60-х гг. прошлого века как протест против цветных революций и локальных войн, что вели армии США и ее союзники по блоку. Не путать с современными хипстерами.

3. Замечание, возникшее неожиданно: как бы «вдогонку» уже вводимым дополнениям, которым вдруг реальная действительность преподнесла сюрприз: аргументы неоспоримой доказательности - с конца мая 2020 г. началось поистине планетарное протестное движение, придя на смену планетарной гражданской самоизоляции стран, вызванной пандемией короновируса, и которое можно уподобить средневековым крестьянским восстаниям, и суть которого ещё предстоит осмыслить. И пока создавалась сноска к «451 градус по Фаренгейту» (по рекомендации редактора) международные СМИ сообщили, что в США на фоне массовых протестов и погромов ввели цензуру по расовому принципу, и начали с хрестоматийного фильма «Унесённые ветром» (1936) - изъяв с цифровых носителей кино, и романа «Убить пересмешника» Харпер Ли (Пулитцеровская премия 1961), на которых воспитывались поколения (и не только в Америке), ставшие классикой «мирового искусства», - и этот популистский жест сродни мародёрскому, и только свидетельствует, что дух маккартизма въелся в лимфу всего американского общества, в основе которого протестантская инквизиция, борьба за исключительность и «гонения на ведьм». 
увернуться от летящего в тебя снежка или комка грязи, но когда ваше сознание забрасывают камнями, и летальный исход практически предрешён, то избежать его возможно, если соблюдать правила гигиены, для Сознания прежде всего.

«451 градус по Фаренгейту» - это также притча о готовящейся экспансии агрессивного государства, что растянется тлеющим болотом по миру, принуждая насилием и обманом сам мир к трансформации и смыслов, и ценностных категорий (добра, зла, любви, красоты, знания и т.п.), тех смыслов культуры, что у каждого народа оказываются общими, поскольку закреплены традицией (литературной, этической, музыкальной, народной, бытовой), и тем самым узаконивая обезличивание, как бы подталкивая, пробуждают никчёмность современного человека, которого вынуждают стать «отщепенцем» - человеком без исторических корней, без родины, без дома предков, манкуртами примитива, погружая в суррогаты 'общества потребления'. Но всякое тление сменяется пламенем - npomecm всnыхиваеm как огонь, и рано или поздно, но именно тогда, когда терпеть холод отчуждения становится невмоготу.

РЕВОЛЮЦИЯ - ЭТО ТО СОСТОЯНИЕ ОБЩЕСТВА, В КОТОРОМ ВСЕ ПОЗВОЛЕНО, И КаК «СОстояние» его внедряли циники (гибристы), которым нечего было терять, ибо ничего не имели за душой, кроме растерянности и эго, и как 'состояние' революция приглянулась цивилизации, которая адаптировала ее под «моду», и приучила человечество бороться за 'право обладания', при этом революционность стала отождествляться с 'борьбой за свободу', а последняя, плутая в трех соснах, не замечая трансформации, приводит к стене резервации тоталитарного режима. Каким образом? - неведением, и нежеланием знать больше циркуляра. Состояние, в котором человеку все позволено, довольно бесформенно, а само общество аморфно и беспамятно, и оттого оно не замечает 'трансформации' происходящей с ним, поскольку приучено купировать Историю - обрезать её кудри, словно собачьи хвосты, и оттого оно легко встаёт на колено, ибо Сознание давно стоит на коленях, и пока эта коленопреклонённая мятежность не вглядится в себя, хотя бы через зеркало метафор, - тоталитарное и тотальное будет пеленать, направляя, общество, которое не ощущало своей трансформации, как не признавал своего «превращения» Грегор Замза", не принимая своим 'отражением' членистоногого насекомого, окажется податливым ко всякой манипуляции и информации, склоняясь к любой аффектации, оно будет дрожать и кликушествовать, и пока не осознает пределы своего Сознания (при этом каждый в отдельности и каждый в своей неразделённой совокупности - 'totius'), то есть его способности к постижению всего и вся, то ощущения случившейся с ним 'трансформации' не возникнет, как не возникнет и понимание «красоты мира» как целокупности «гармонического» и «человеческого». Предчувствие тотальной трансформации ${ }^{2}$ происходящей в людском обществе, что само себя опустошило, спалив Смысл, как предчувствие большой беды: исчезновение перспективы существованию (не будущего - что просто «временная категория»), как прозревание экзистенциального провала, в который летело 'общество потребления', сметая все основы существования огнём рационального лицемерия, - именно это «прозрение времени и пространства» выразил в своём романе Брэдбери. И «тотальный» в этом сочетании обнажает целокупное изменение, всеобъемлющее, как оборачивание, что демонстрировал собою Протей, претерпевая полное оборачивание: из рыбы в вепря. Пожарный, который своей прямой профессиональной обязанностью считает «разжигание огня», а не «тушение пламени», и есть доказательство 'свершённой трансформации', поскольку носитель профессии забыл смысл слова, что определяет его род деятельности, равно как пекарь, «выпекая», стал бы химраствором проводить обработку булочек, превращая их в «яд» (аналогии можно развернуть), и может быть он и хотел бы вспомнить этимологию слов, да вот незадача - словари, как «враги народа» были сожжены первыми. И вот в этом настоящая катастрофа общества - в тотальной пропаже смыслов, утрате ценой не искажения, но полного замещения «иным». Символы трансформации могут быть разными: от бабочки и Протея до шляпы-слона Экзюпери, но суть их неизменна: они несут «эсэмэску» о превращении, состоявшемся. «Дикие лебеди» Г.-Х. Андерсена как символ трансформации через ускользающее восприятие и тож-

1. Персонаж рассказа Ф. Кафки «Превращение» (1912).

2. От: «transformo, avi, atum, are «преобразовывать», «превращать»; transformis - «переменяющийся», «изменяющий свой вид» «изменённый», «преобразованный»» [4, С. 656]. 
дественность резонансного всплеска, позволили моему Сознанию перевести метафору Брэдбери в символ трансформации, приоткрыв 'явки и пароли' этого законспирированного с 1953 года восприятия борьбы с инакомыслием, что так напугало крепкого газетчика Рэя, и он сумел предупредить о пролегоменах и всполохах грядущего упадка «огнём по Фаренгейту», сделав его символом тотальной трансформации. Она уже идёт. Но как «тление» она будет долгой.

Двуединство представлений древних греков приучает их не только к нестабильным системам: к революциям, полисной организации, смеху, но и создаёт прецедент в культуре - двойственную модель искусства. Принцип «гротесков»: переходить из одного тела (ипостаси) в другое - покоится на трех китах противоречивого мышления древних греков - это их Протей, в котором стоики видели аллегорию материи, что формировалась и оформляется самой богиней форм - Эйдотеей. Такое аллегорическое мышление могло сформироваться только Мифом и благодаря Мифу - этой колыбели «политической рефлексии» человека, которая, по сути, есть мышление человека, что само себя мыслит, отвергая предыдущее, подвергая сомнению, словно змея, скидывая кожу, и тем самым: продвигаясь на длину собственного тела - пролагает себя в действительности - и с этого «первого иага» начинается политическая свобода человека, которая обеспечит ему институализацию, сформировав политическую стратегию и образ жизни. Заметим, русский философ А. Пятигорский называл политической рефлексией мышление, направленное на политическую философию государства.

Именно Эйдотея подсказала Менелаю пути возвращения на родину: схватить спящего Протея и не выпускать из рук какую бы форму тот ни принимал, пока не окажется в своём настоящем облике 'старца' и не даст совет о возвращении в Спарту, и не раскроет судьбу героев Троянской битвы, - то есть предложила «форму» исполнения желания: материализуя словом, способствовала осуществиться предсказанному и задуманному, и тем самым структурировала материю (и мысли в том числе, что материальна «вопреки»), формализуя буквально: направляя и организуя, и если буквально: близко к источнику, то пробуждала стратегическую сноровку царя, попавшего в затруднительное положение и рвуще- гося к себе на родину - в государство: владеть и властвовать. Оборотничество морского божества (Протея) принималось за норму, тогда как 'бесповоротность', означавшую закон предопределённости, изначальной заданности, грек классической эпохи стремился не только избежать, но осмеять. Эйдотея как порождение 'материи' структурирует сознание, форматируя мышление буквально: лексикой языка, синтаксисом - организованным движением слов, и метафорой, помогая мыслить, ибо думаем мы словами.

Критика новейших заблуждений, обнажив формальный подход логических посылок, свидетельствует о том, что человечество совершило эволюционный отскок - на 2,5 тыс. лет, переварив парадокс лжеца в парадокс циника: широко и свободно применяя двоичный код лицемерия, демонстрируя свой коварный, но увы, формальный разум, привыкнув склонять к «формализму» логику, утратившую форму Смысла. Формальность Обмана как приём 'цветущего лицемерия', и как ухищрение Сознания, что растерялось или потерялось в трех соснах, сводит жизнь к определённой форме, которая не требовательна к эмоциям, что предполагают искренность и доверие, и формально приучает к подражательности и ритуальности - выхолощенности поступка, - и это поистине откат в архаику - векам вероломным и темным, что, по сути, оказывается 'программным обеспечением' мышления современного человека. Формальный разум демонстрирует готовность обмануть и обмануться, как в древние времена в охотничьей битве, то есть воспринимает ложь априори, имея гаджет в кармане и университет за душой, поклоняясь насилию и мечтая о власти (включая суррогаты этих понятий), существуя формально вне конфликтной ситуации, но тяготея и провоцируя конфликт. Такой разворот наших размышлений к нашему концепту «Троянский терроризм» не просто свидетельство того, что автор находится под влиянием своей идеи, - напротив, это Идея, обретя Образ понятия: захват как формальность, владеет обществом на правах суверена, устанавливая свой Принципат, демонстрируя свободу воли и вполне марсианские хроники существования, уповая на 'множественную единичность' сознания, что структурируется извне и формальным методом кубофутуризма. Формальность предрассудка, выхолащивая жизнь как жизнь других, снимает всякую логику как «излишнюю формаль- 
ность», готовя почву для безумочного бытования: воплощая быт наглеца как бытие инфанта - непрерывное в своей праздной установке, покрывая патиной лицемерной лжи само Сознание. Мы не рождаемся слепыми, но Сознание - наше зрение - проводник в бесконечное и познаваемое, а потому эта статья невольно раскрывает, как критика чистого разума легко трансформируется в критику формального разума, незатейливо обнажая морфологию авторского сознания, для которого концепт "троянский терроризм» и концепт "свингующее сознание» образуют либертианское танго, в 'неслиянии' которого рождается Образ Понятия.

\section{БИБЛИОГРАФИЯ}

1. Aristotelis fragmenta selecta / Recognovit W. D. Ross. Oxford, 1955. В русском переводе: Аристотель. О памяти. / Аристотель. Протрептик. О чувственном восприятии. О памяти. Пер. на рус. Е. В. Алымовой. СПб.: Изд-во С.-Петерб. ун-та, 2004. - 183 с.

2. Греческие эпиграммы (VII век до н. э. - IX век н. э). Перевод, статья и примечания Л. В. Блуменау. - Москва-Ленинград: ACADEMIA, 1935. - 316 с.

3. Краткий словарь латинских слов, сокращений и выражений / Сост. В. Купреянова, Н. Умнова. - М.: TEPPA, 1996. -96 c.

4. Латинско-русский словарь. / О. А. Петрученко. Репринт 9-го издания 1914 г. - М.: Эксмо, 2017.

5. Лурье С. Я. Демокрит. Тексты. Перевод. Исследования. - Ленинград: Изд-во Наука, 1970. - 664 с.

6. Меньшикова Е. Р. Апология Смеха: сингулярность «гротескного сознания» в системе локальных войн, или умолчания Аристотеля как «срыв потока». / Материалы Всероссийского научного семинара с международным участием «Corpus Aristotelicum в XXI веке» (14-15 апреля, Крымский федеральный университет им. В. И. Вернадского, Ялта) - Ялта, 2016.

7. Меньшикова Е. Р. Миф как натуральный обмен. // CredoNew, 2017, №№ 1, 2, 3.

8. Меньшикова Е. Р. Музыкальная скрижаль искусства: симфонизм как художественный метод 20-х. // Вопросы литературы, 2009, № 4. С. 167-190.

9. Меньшикова Е. Р. Натуральный ландшафт философии (политическая рефлексия Гераклита и Аристотеля). 4Ч. 1, 2. // Дом Бурганова. Пространство культуры, 2019, № 4. 2020, № 1.

10. Меньшикова Е. Р. Парадокс лжеца: возможна ли жизнь вне Сознания, или критика формального разумa. // CredoNew, 2020, № 1. C. 258-300.

11. Меньшикова Е. Р. Протей, затерянный в саду Гесперид, или экзистенциальный скачок гротеска как антикризисная модель и как смыслосохраняющий принцип искусства. // «Дом Бурганова. Пространство культурыз». - Москва, 2011. № 1. С. 8-22.

12. Меньшикова Е. Р. Редуцированный смех Юрия Олеши. // Вопросы философии, 2002, № 10. С. 75-85.
13. Меньшикова Е. Р. Рондо Мифа: «Троянский терроризм» как идея исключительности, или summum bonum Цезаря: насильем покоряйте мир. // Credo New, 2019, № 2. C. 348-377.

14. Меньшикова Е. Р. Свингующее Сознание или «самоорганизующийся Хаос» как резонансная система. // Credo New, 2019, № 3. C. 268-309.

15. Меньшикова Е. Р. Смех Протея: феномен гротескного сознания. - СПб.: Алетейя, 2015. - 340 с.: ил.

16. Меньшикова Е. Р. «Смех как модерн, или реликтовое излучение мениппеи («Невельский кружок философии» М. Бахтина vs «Прокрида» О. Фрейденберг)». Тезисы. / «Русский Логос-2: модерн-границы контроля» (Материалы международной Философской конференции «Русский Логос: горизонты осмысления» (25-28 сентября, 2019, Санкт-Петербург). В 2-х т. - СПб.: Издво РГПУ им. А.И. Герцена, 2019. С. 496-499.

17. Меньшикова Е. Р. Трагифарс и диссипативность как признаки карнавализованного сознания. / Сакральное и секулярное в русской культуре: Сер. «На перекрестке культур». - М., 2009.

18. Меньшикова Е. Р. Троянский терроризм как принципат Обмана, или в объятиях терракотовой саранчи (этимологические надкрылья virtus). ЧЧ. 1, 2, 3. // Credo New, 2018, №№ 3-4. 2019. № 1.

19. Меньшикова Е. Р. Троянский терроризм как установленный порядок (disciplina), или кочующий колонат (миссия Мифа в пространстве Т. Мора «Утопия»). // Credo New, 2018, № 2. C. 189-221.

20. Меньшикова Е. Р. Троянский терроризм: условие эволюции или месть колонистов? (к проблеме «свой) чужой») ". // Credo New, 2018, № 1. C. 183-214.

21. Меньшикова Е. Р. Философия Мифа vs натурфилософы: монологи Гесиода как первоэлементы сократических диалогов. Тезисы. // Прагматика философского текста: материалы Всероссийской научной конференции «XV Таврические философские чтения «Анахарсис»» (Республика Крым, Судак. Новый Свет, 16-19 сентября 2019). - Симферополь, Крымский федер. ун-т им. В. И. Вернадского. 2019. С. 113-115. 
22. Меньшикова Е. Р. Философия Смеха или «гротескное сознание» как плата за существование. Тезисы. / «Русский Логос: горизонты осмысления» (Материалы международной Философской конференции 25-28 сентября, 2017, Санкт-Петербург). В 2-х тт. - Санкт-Петербург, 2017. т. 2, С. 173-182.

23. Меньшикова Е. Р. Формула аструктурности Сознания: от интеграла доверия и летучих фракталов смысла к обретаемой сингулярности. // Credo New, 2019, № 4. C. 277-311.

24. Menshikova E. R. The double axe of Troy: the mission of Myth as a nomadic colonatus or Procrustean space of being. Abstracts. / XXXth International Conference of Philosophy "Polis, Cosmopolis and Globalisation" (SamosPythagorion: $20^{\text {th }}-26^{\text {th }}$ July 2018). Paper Abstracts. - Samos, 2018.

25. Menshikova E. R. Laughing Scaffold of Perception or Antiworlds of Crying Lira: how and why "grotesque Consciousness works». // TSC'2017 THE SCIENCE OF CONSCIOUSNESS. Paper Abstracts. June 5-10, 2017. La Jolla, California.

26. Menshikova E. R. Laughing scaffold perception or antiworlds crying lira: how and why "grotesque consciousness" works. // International Journal of Cultural Heritage, 2018, N.1 [International Journal of Cultural Heritage, 3, 11-37 (https://iaras.org/iaras/home/caijch/ laughing-scaffold-perception-or-antiworlds-crying-lirahow-and-why-grotesque-consciousness-works)].

27. Menshikova E. R. Metaphor - a volatile quantum of Meaning, or formula of structuredness of Consciousness. / TSC'2020 THE SCIENCE OF CONSCIOUSNESS. Paper Abstracts. April 13-18, 2020. Tucson, Arizona [ September 14-18, 2020, online-conference].

28. Menshikova E. R. The Natural Landscape of Philosophy (political reflaction of Heraclitus and Aristotle). $/ / 29^{\text {th }}$ International Conference of Philosophy "Greek moral and political philosophy-From Pre-Socratics to NeoPlatonism" (Jule 7-11, 2017, Rhodes). Paper Abstracts. Rhodes, 2017.

29. Menshikova E. R. The Natural Landscape of Philosophy (The Political Reflection of Heraclitus and Aristotle). // Philosophy Study, V. 8, N.1, 2018.

30. Menshikova E. R. Quasars of Introjection, or as Consciousness Swings. // TSC'2019 THE SCIENCE OF CONSCIOUSNESS. Paper Abstracts. June 25-28, 2019, Interlaken, Switzerland. - Collegium Helveticum Zurich 2019. P. 266.

31. Menshikova E. R. Singularity Laugh or Grotesque Consciousness in Relation to Aristotle's Poetics. // XXIV World Congress of Philosophy "The Philosophy of Aristotle".
Abstracts. - Athens 09-15 July 2016. University of Athens, School of Philosophy University Campus - Zografas.

32. Menshikova E. R. Swinging Consciousness, or Selforganizing Chaos as a Resonant System. // Philosophy Study, V. 9, N. 1, 2019.

33. Menshikova E. R. The Trojan Terrorism as an Established Order (Disciplina), or the Nomadic Colonatus (Mission of Mith in the space of Sir Thomas More's "Utopia"). // International Relations and Diplomacy, February 2018, Volume 6, Number 2, (Serial Number 53).

34. Menshikova E. R. Trojan Terrorism as a Principate of Deception, Or in the Arms of the Terracotta Locust (Ethymological Wing Cases of Virtus). Part I. // International Relations and Diplomacy, November 2019, Volume 7, Number 11, (Serial Number 74).

35. Мифологический словарь: Кн. Для учителя / М. Н. Ботвинник, Б. М. Коган, М. Б. Рабинович, Б. П. Селецкий - 4-е изд., испр. и перераб. - М.: Просвещение, 1985. - 176 с., ил.

36. Словарь литературоведческих терминов. - М., 1974.

37. Фрейденберг О. М. Миф и литература древности. - М.: «Восточная литература» РАН, 1998. - 800 с.

38. Фрейденберг О. М. Образ и понятие. / Фрейденберг О. М. Миф и литература древности. - М.: Изд. фирма «Восточная литература» РАН, 1998. С. 223-622.

39. Фрейденберг О. М. Поэтика сюжета и жанра. - M., 1997. - 448 c.

40. Pyatigorskiy A. What this a political philosophy: thinkings and considerations. - M.: Izdatelstvo "Europa", 2007. 